\title{
The distribution of active iron-cycling bacteria in marine and freshwater sediments is decoupled from geochemical gradients
}

\author{
Julia M. Otte, ${ }^{1}$ Johannes Harter, ${ }^{1}$ Katja Laufer, ${ }^{1,2}$ \\ Nia Blackwell, ${ }^{3}$ Daniel Straub, ${ }^{3}$ \\ Andreas Kappler ${ }^{1,2}$ and Sara Kleindienst (D) ${ }^{3 *}$ \\ ${ }^{1}$ Geomicrobiology, Center for Applied Geosciences, \\ University of Tübingen, Germany. \\ ${ }^{2}$ Center for Geomicrobiology, Department of Bioscience, \\ Aarhus University, Denmark. \\ ${ }^{3}$ Microbial Ecology, Center for Applied Geosciences, \\ University of Tübingen, Germany.
}

\section{Summary}

Microaerophilic, phototrophic and nitrate-reducing $\mathrm{Fe}$ (II)-oxidizers co-exist in coastal marine and littoral freshwater sediments. However, the in situ abundance, distribution and diversity of metabolically active $\mathrm{Fe}$ (II)-oxidizers remained largely unexplored. Here, we characterized the microbial community composition at the oxic-anoxic interface of littoral freshwater (Lake Constance, Germany) and coastal marine sediments (Kalø Vig and Norsminde Fjord, Denmark) using DNA-/RNA-based next-generation 16S rRNA (gene) amplicon sequencing. All three physiological groups of neutrophilic $\mathrm{Fe}$ (II)-oxidizing bacteria were found to be active in marine and freshwater sediments, revealing up to $0.2 \%$ anoxygenic photoferrotrophs (e.g., Rhodopseudomonas, Rhodobacter, Chlorobium), $0.1 \%$ microaerophilic Fe(II)oxidizers (e.g., Mariprofundus, Hyphomonas, Gallionella) and $0.3 \%$ nitrate-reducing $\mathrm{Fe}$ (II)-oxidizers (e.g., Thiobacillus, Pseudomonas, Denitromonas, Hoeflea). Active $\mathrm{Fe}$ (III)-reducing bacteria (e.g., Shewanella, Geobacter) were most abundant (up to $2.8 \%$ ) in marine sediments and co-occurred with cable bacteria (up to $4.5 \%$ ). Geochemical profiles of $\mathrm{Fe}(\mathrm{III}), \mathrm{Fe}(\mathrm{II})$, $\mathrm{O}_{2}$, light, nitrate and total organic carbon revealed a redox stratification of the sediments and explained $75 \%-85 \%$ of the vertical distribution of microbial taxa, while active Fe-cycling bacteria were found to

Received 24 October, 2017; revised 26 April, 2018; accepted 26 April, 2018. ${ }^{*}$ For correspondence. E-mail sara.kleindienst@unituebingen.de; Tel. +49-7071-29-74701; Fax +49-7071-29-5059. be decoupled from geochemical gradients. We suggest that metabolic flexibility, microniches in the sediments, or interrelationships with cable bacteria might explain the distribution patterns of active Fecycling bacteria.

\section{Introduction}

Iron $(\mathrm{Fe})$ is an essential redox-active element and abundant in the environment (Canfield et al., 1993), typically found in the redox states of $\mathrm{Fe}(\mathrm{II})$ and $\mathrm{Fe}(\mathrm{III})$. In the biogeochemical Fe cycle, Fe is transformed between these two redox states via several abiotic and biotic processes (Melton et al., 2014b). Under neutral pH conditions, abiotic reactions include $\mathrm{Fe}(\mathrm{III})$ reduction by reduced sulfur species or humic substances and $\mathrm{Fe}(\mathrm{II})$ oxidation by oxygen, oxygen radicals, $\mathrm{Mn}(\mathrm{IV})$ oxides or reactive nitrogen species, such as nitrite or nitric oxide (Melton et al., 2014b). In addition, biotic processes include Fe(II) oxidation by phototrophic (PFeOx), microaerophilic (MFeOx) and nitrate-reducing $\mathrm{Fe}(\mathrm{II})$-oxidizers (NRFeOx) (Widdel et al., 1993; Straub et al., 1996; Emerson and Moyer, 1997; Laufer et al., 2016), as well as Fe(III) reduction by dissimilatory $\mathrm{Fe}(\mathrm{III})$-reducing bacteria (Lovley, 2013; Melton et al., 2014b). In marine and freshwater sediments, the biogeochemical $\mathrm{Fe}$ cycle is connected to carbon, nitrogen and sulfur cycles by $\mathrm{Fe}(\mathrm{II})$ oxidation and $\mathrm{Fe}$ (III) reduction processes (Canfield, 1989; Emerson and Moyer, 1997; Roden, 2004; Kappler and Straub, 2005; Li et al., 2012). Therefore, investigating microbially mediated Fe-cycling is crucial to understanding geochemical cycles in environmental systems.

Known anoxygenic PFeOx, so called photoferrotrophs (Widdel et al., 1993), e.g., Rhodovulum iodosum (Wu et al., 2014), Rhodopseudomonas palustris sp. strain TIE-1 (Jiao et al., 2005), Rhodobacter ferrooxidans sp. strain SW2 (Ehrenreich and Widdel, 1994) and Chlorobium ferrooxydans (Heising et al., 1999), belong to purple sulfur, purple nonsulfur and green sulfur anoxygenic phototrophic bacteria respectively, and are characterized to be metabolically flexible (Widdel et al., 1993; Heising et al., 1999; Jiao et al., 2005). MFeOx mainly affiliate with Betaproteobacteria, e.g., 
Gallionella spp. (Kucera and Wolfe, 1957; Hallbeck and Pedersen, 1991), Leptothrix spp. (Winogradsky, 1888; Fleming et al., 2011) and Sideroxydans spp. (Emerson and Moyer, 1997; Weiss et al., 2007) as well as with the class Zetaproteobacteria, represented by the genera Mariprofundus (Emerson et al., 2007) and Ghiorsea (Mori et al., 2017). NRFeOx, e.g., Thiobacillus, Pseudomonas and Hoeflea, couple the reduction of nitrate to the oxidation of $\mathrm{Fe}(\mathrm{II})$, which leads to the formation of gaseous products such as $\mathrm{NO}, \mathrm{N}_{2} \mathrm{O}$ and $\mathrm{N}_{2}$ (Straub et al., 1996). Fe(III)-reducing bacteria are phylogenetically diverse with members affiliating with Gamma-, Beta-, Epsilon-, Deltaproteobacteria and a few additional genera (e.g., Geothrix, Bacillus) (Lovley, 2013).

Microorganisms that oxidize $\mathrm{Fe}$ (II) and reduce $\mathrm{Fe}$ (III) have been reported from various Fe-rich environments ( $>1 \mathrm{wt} \% \mathrm{Fe}$ ) such as hot springs (Kasama and Murakami, 2001), ferrous hydrothermal vents (Emerson and Moyer, 2010; Edwards et al., 2011; Fitzsimmons et al., 2014), Fe seeps and springs (Blöthe and Roden, 2009; Hegler et al., 2012), rice paddy soils (Li et al., 2016; Peng et al., 2016), salt lake sediment (Emmerich et al., 2012), microbial mats in the arctic tundra and in close proximity of hydrothermal vents (Emerson et al., 2015) and ponds (Bruun et al., 2010). In contrast, iron-poor environments (with relatively low, i.e., micromolar, concentrations of $\mathrm{Fe}(\mathrm{II}))$ remained relatively unexplored, however, very recently, microbial Fecycling has also been described for environments with low Fe content (Laufer et al., 2016; Chiu et al., 2017).

General molecular assays for catabolic target genes of $\mathrm{Fe}$ (II)-oxidizing bacteria (as well as of $\mathrm{Fe}$ (III)-reducing bacteria) are lacking, due to mechanistic differences of microbial $\mathrm{Fe}(\mathrm{II})$ oxidation (Kato et al., 2015; Shi et al., 2016), and, thus, microbial community studies are currently needed to explore the in situ abundance, distribution and diversity of $\mathrm{Fe}(\mathrm{II})$-oxidizers in the environment. A study, characterizing the microbial community based on 16S rRNA gene analysis in Baltic Sea sediments, showed that Fe(III)-reducing bacteria (e.g., Desulfobacter, Geobacter and Pelobacter) were more abundant near the $\mathrm{Fe}(\mathrm{III}) / \mathrm{Fe}(\mathrm{II})$ redox boundary, while $\mathrm{Fe}(\mathrm{II})$-oxidizing bacteria (e.g., Mariprofundus and Gallionella) were detected in comparatively lower abundance (Reyes et al., 2016). Another DNA-based microbial community study of Baltic Sea sediments found $\mathrm{Fe}$ (III)-reducing bacteria of the orders Myxococcales and Desulfuromonadales positively correlating with total $\mathrm{Fe}$ in surface sediments (Edlund et al., 2008; Sinkko et al., 2011). In addition, a DNA-based microbial community study of the water column of Lake Cadagno, characterized by low Fe concentrations, detected Fe(II)-oxidizing bacteria, e.g., Chlorobium and Rhodomicrobium and $\mathrm{Fe}$ (III)-reducing bacteria, e.g., Rhodoferax and Geothrix (Berg et al., 2016).

The co-existence of all physiological types of $\mathrm{Fe}(\mathrm{II})$-oxidizing and $\mathrm{Fe}$ (III)-reducing microorganisms in marine sediments was demonstrated by cultivation-dependent most probable number experiments (Laufer et al., 2016). However, the distribution of active Fe-metabolizing bacteria was neither identified nor localized in situ in littoral freshwater or coastal marine sediments. Moreover, it remained unknown if the distribution of active $\mathrm{Fe}$ metabolizing bacteria in the environment follows, as expected, the geochemical gradients of oxygen, light and $\mathrm{Fe}$ (II) (Schmidt et al., 2010). Here, we analysed the distribution, abundance, diversity and co-existence of present and active Fe-cycling communities in six marine and two freshwater sediment cores using DNA- and RNA-based $16 \mathrm{~S}$ rRNA (gene) analyses respectively, and explored the distribution patterns of active Fe-cycling bacteria with respect to geochemical gradients.

\section{Results}

\section{Geochemical characterization of the sediments}

The marine sediments from Norsminde Fjord and Kalø Vig and the freshwater sediment from Lake Constance were geochemically distinct (Table 1). In the marine and freshwater sediments, light and oxygen were only detected in the upper $3 \mathrm{~mm}$. The highest values of dissolved organic carbon (DOC) were detected in the porewater from Lake Constance sediment $\left(7.5 \mathrm{mg} \mathrm{I}^{-1}\right)$, while the porewater from Kalø Vig sediment contained only $3.5 \mathrm{mg} \mathrm{I}^{-1}$ and from Norsminde Fjord sediment around $5 \mathrm{mg} \mathrm{I}^{-1}$ of DOC. The concentrations of nitrate in the porewater of both marine sediments and in Lake Constance sediment were low, i.e., with maximum values of $18 \mu \mathrm{M}$ in Kalø Vig, 21-65 $\mu \mathrm{M}$ in Norsminde Fjord, and 50-80 $\mu \mathrm{M}$ in Lake Constance. Dissolved Fe(II) concentrations in the porewater of the sediment were maximal at around $70 \mu \mathrm{M}$ in Kalø Vig, $90 \mu \mathrm{M}$ in Norsminde Fjord and $76 \mu \mathrm{M}$ in Lake Constance sediments.

\section{Microbial community characterization of the sediments}

Absolute bacterial and archaeal 16S rRNA (gene) copy numbers remained relatively stable over the investigated sediment depth and among replicate sediment cores from Norsminde Fjord, Kalø Vig and, Lake Constance. Bacterial abundance was highest at 0-3 mm [0.4-6 $\times 10^{8} 16 \mathrm{~S}$ rRNA (gene) copies per $g$ wet sediment] compared to the deeper layers in both marine sediments, while the archaeal abundance was highest at deeper sediment layers [20$30 \mathrm{~mm} ; 0.6-1 \times 10^{8} 16 \mathrm{~S}$ rRNA gene copies per g wet sediment] in both marine sediments (Supporting Information Figs. S1 and S2). In the freshwater sediment, the highest bacterial and archaeal abundances were found at 3$10 \mathrm{~mm}$ sediment depth $\left[0.1-1 \times 10^{8}\right.$ bacterial $16 \mathrm{~S}$ rRNA (gene) copies g per wet sediment; $0.5-1 \times 10^{8}$ archaeal $16 \mathrm{~S}$ rRNA gene copies per $\mathrm{g}$ wet sediment].

While diversity indices were similar among all investigated sediments (Supporting Information Table S1), each 
Table 1. Geochemical parameters of marine coastal sediments from Kalø Vig and Norsminde Fjord (Aarhus Bay, Denmark), as well as freshwater sediments from Lake Constance (Germany).

\begin{tabular}{|c|c|c|c|c|c|c|c|c|c|c|c|}
\hline $\begin{array}{l}\text { Sediment layers } \\
(\mathrm{mm})\end{array}$ & $\begin{array}{l}\mathrm{O}_{2} \\
(\mu \mathrm{M})\end{array}$ & $\begin{array}{l}\text { Light } \\
(\%)\end{array}$ & $\begin{array}{l}\text { Redox } \\
\text { potential } \\
(\mathrm{mV})\end{array}$ & $\mathrm{pH}$ & $\begin{array}{c}\mathrm{Fe}(\mathrm{II})_{\text {diss }} \\
(\mu \mathrm{M})\end{array}$ & $\begin{array}{c}\mathrm{Fe}(\mathrm{II})_{\text {total }} \\
(\mu \mathrm{M})\end{array}$ & $\begin{array}{c}\mathrm{Fe}(\mathrm{III})_{\text {diss }} \\
(\mu \mathrm{M})\end{array}$ & $\begin{array}{c}\mathrm{Fe}(\mathrm{III})_{\text {total }} \\
(\mu \mathrm{M})\end{array}$ & $\begin{array}{c}\mathrm{DOC} \\
\left(\mathrm{mg} \mathrm{I}^{-1}\right)\end{array}$ & $\begin{array}{l}\mathrm{NO}_{3}^{-} \\
(\mu \mathrm{M})\end{array}$ & $\begin{array}{l}\text { Sulfide } \\
(\mu \mathrm{M})\end{array}$ \\
\hline \multicolumn{12}{|c|}{ Kalø Vig } \\
\hline $0-3$ & $0-250$ & 100 & $100-200$ & $7.5-8.3$ & 0.2 & 60 & 0.05 & 10 & 3.5 & 18 & n.d. \\
\hline $3-10$ & 0 & 0 & $50-100$ & 7.5 & 0.2 & 60 & 0.05 & 10 & 3.5 & 0 & n.d. \\
\hline 10-20 & 0 & 0 & 50 & 7.5 & 0.2 & 60 & 0.05 & 10 & 3.5 & 0 & n.d. \\
\hline 20-30 & 0 & 0 & 50 & 7.3 & $0.2-0.3$ & $60-70$ & $0.05-0.1$ & 10 & 3.5 & 0 & n.d. \\
\hline \multicolumn{12}{|c|}{ Norsminde Fjord } \\
\hline $0-3$ & $0-250$ & 100 & $-100-380$ & $7.5-8.2$ & 0.2 & 70-90 & 0 & $10-20$ & 4.9 & 64 & n.d. \\
\hline $3-10$ & 0 & 0 & $-100-100$ & 7.5 & 0.2 & $70-80$ & 0 & $5-10$ & 4.9 & 21 & n.d. \\
\hline $10-20$ & 0 & 0 & -100 & 7.5 & $0.2-0.25$ & $40-80$ & 0 & 5 & 4.9 & 0 & n.d. \\
\hline $20-30$ & 0 & 0 & -100 & 7.3 & $0.25-0.3$ & 40 & 0 & 5 & 4.9 & 0 & n.d. \\
\hline \multicolumn{12}{|c|}{ Lake Constance } \\
\hline $0-2$ & 150 & 100 & 293 & 7.6 & 6 & 53.8 & n.m. & n.m. & 7.6 & 53.8 & 6 \\
\hline $2-4$ & 3 & $2-4$ & 190 & 7.6 & 3.5 & 58.1 & n.m. & n.m. & 7.6 & 58.1 & 3.5 \\
\hline $4-6$ & 0 & 0 & 117 & 7.5 & 3.7 & 76.3 & n.m. & n.m. & 7.5 & 76.3 & 3.7 \\
\hline $6-10$ & 0 & 0 & 110 & 7.4 & 2.9 & 47.9 & n.m. & n.m. & 7.4 & 47.9 & 2.9 \\
\hline $10-15$ & 0 & 0 & 91 & 7.3 & 4.7 & 52.5 & n.m. & n.m. & 7.3 & 52.5 & 4.7 \\
\hline
\end{tabular}

n.d., not detectable/below level of detection; n.m., not measured.

field site had distinct microbial community structures. DNA and RNA-based analyses, comparing present and active microbial communities, revealed highly significant differences (Permanova, $P<0.001$ ) at the two marine field sites and at the freshwater site respectively (Supporting Information Fig. S3, Tables S2 and S3). Highly significant differences (Permanova, $P<0.001$ ) were also found between the active microbial communities at the freshwater field site and those found at the two marine field sites (Supporting Information Fig. S3). All sediments were dominated by bacteria (98\%) (Supporting Information Fig. S4). In the marine sediments, Proteobacteria dominated (Kalø Vig = DNA: 39\%, RNA: 53\%; Norsminde Fjord=DNA: 41\%, RNA: 65\%), including Gamma-, Delta-, Alpha- and Betaproteobacteria. In addition, Cyanobacteria (Kalø Vig=DNA: 9\%, RNA: 18\%; Norsminde Fjord=DNA: 3\%, RNA: $5 \%$ ) and Bacteroidetes (Kalø Vig = DNA: 24\%, RNA: $22 \%$; Norsminde Fjord=DNA: 24\%, RNA: 18.5\%) were present at the marine sites. Similar to the marine sediments, freshwater sediments at Lake Constance were dominated by Proteobacteria (DNA: 35\%, RNA: 38\%) which were affiliated with Gamma-, Delta-, Alpha- and Betaproteobacteria. In addition, Cyanobacteria (DNA: 19\%, RNA: $28 \%$ ) and Bacteroidetes (DNA: 15\%, RNA: $13.5 \%$ ) were abundant in the freshwater sediments.

\section{Diversity and relative abundance of Fe-metabolizing microorganisms}

All three physiological types of $\mathrm{Fe}(\mathrm{II})$-oxidizing bacteria and known $\mathrm{Fe}$ (III)-reducing bacteria were detected in the marine and freshwater sediments (Figs. $1 \mathrm{~A}$ and 2;
Supporting Information Table S4), including Femetabolizing isolates obtained from the same field sites (Supporting Information Table S5). Fe-metabolizers were phylogenetically diverse, partly forming specific marine or freshwater habitat clusters (Fig. 2). Since active Fe-cycling bacteria were of particular interest, in-depth analyses were performed focusing on RNA-based findings. Analysing separate groups of Fe-metabolizers, the relative abundance of $\mathrm{Fe}(\mathrm{II})$-oxidizers was lower $(<0.1 \%)$ compared to $\mathrm{Fe}(\mathrm{III})$-reducers $(<4 \%)$ at the marine field sites (Fig. 1A), while $\mathrm{Fe}(\mathrm{II})$-oxidizers were more abundant $(<2 \%)$ than $\mathrm{Fe}(\mathrm{III})$-reducers $(<0.4 \%)$ at the freshwater site (Fig. 1B).

In the marine sediment, anoxygenic PFeOx were of low relative abundance ( $<0.1 \%$; Fig. $1 \mathrm{~A})$. Compared to Kalø Vig, the anoxygenic PFeOx Rhodopseudomonas and Chlorobium were detected in higher abundance in Norsminde Fjord sediment, particularly in the deeper sediment layers. MFeOx, e.g., Marinobacter and Gallionella, were also detected in low relative abundance $(<0.1 \%)$ at the two marine sites and were probably most active in the organic-rich Norsminde sediment, where abundances were highest in 20-30 mm sediment depth. Mariprofundus was found to be active at one sampling site, in the Norsminde Fjord sediment. Hyphomonas was active in the sediments of both marine field sites. Heterotrophic denitrifiers and NRFeOx showed relatively low abundance $(<0.1 \%)$ in all layers from both investigated marine sampling sites. Most abundant, active NRFeOx affiliated with Thiobacillus in Norsminde Fjord sediment. In addition, most abundant, active $\mathrm{Fe}(\mathrm{III})$-reducers affiliated with Desulfobulbus, Desulfobacterium, Geobacter and Shewanella in all marine sediment layers (Figs. 1A and 2). 


\section{A Fe-cycling microorganisms in coastal marine sediment (Kalф Vig and Norsminde Fjord)}

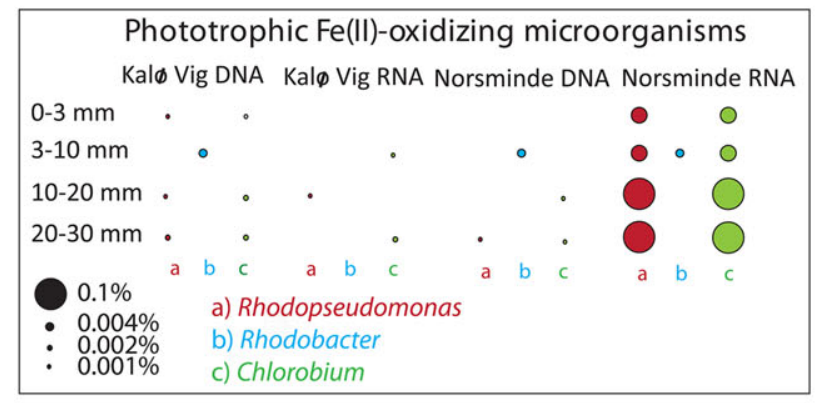

Nitrate-reducing Fe(II)-oxidizig microorganisms Kalø Vig DNA Kalø Vig RNA Norsminde DNA Norsminde RNA

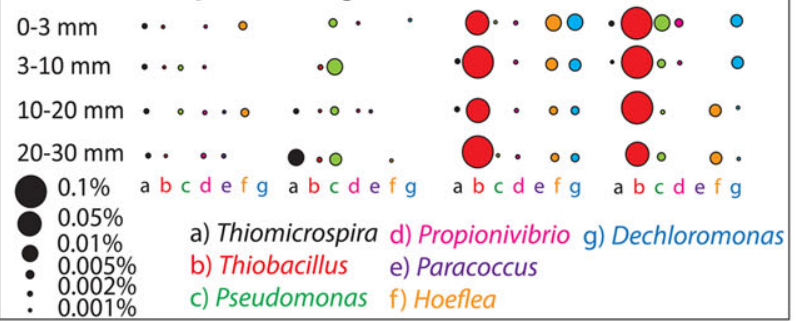

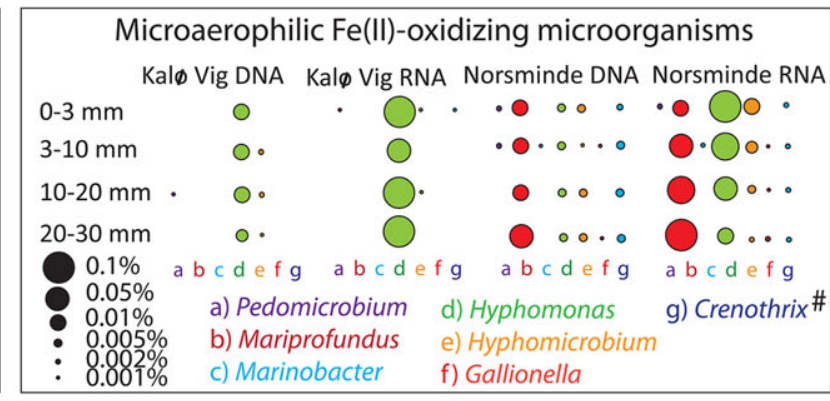

\begin{tabular}{|c|c|c|c|c|}
\hline \multicolumn{5}{|c|}{ Fe(III)-reducing microorgansisms } \\
\hline & Kal $\emptyset$ Vig DNA & Kal $\emptyset$ Vig RNA & Norsminde DNA & Norsminde RNA \\
\hline $0-3 \mathrm{~mm}$ & $\cdots \cdots$ & . & $\bullet \cdots \cdots$ & $\cdots \bullet \cdot$ \\
\hline $3-10 \mathrm{~mm}$ & $\cdot \quad \cdots$ & & $\bullet \cdots$ & $\cdots \circ \bullet \cdot$ \\
\hline $10-20 \mathrm{~mm}$ & ? $\cdot$. & . & $\cdots \bullet \cdot$ & $\cdots \circ \circ \cdot$ \\
\hline $20-30 \mathrm{~mm}$ & $\cdots$ & & $\cdots \cdots$ & $\cdots \circ \circ \cdot$ \\
\hline $4 \%$ & $a b c d e f g$ & $a b c d e f g$ & $a b c d e f g$ & $a b c d e f g$ \\
\hline $\begin{array}{l}2.5 \% \\
1 \% \\
0.5 \% \\
0.2 \% \\
0.1 \% \\
\end{array}$ & \multicolumn{2}{|c|}{$\begin{array}{l}\text { a) Shewanella } \\
\text { b) Geobacter } \\
\text { c) Desulfococcus }\end{array}$} & $\begin{array}{l}\text { d) Desulfobulbus } \\
\text { e) Desulfobacterium } \\
\text { f) Desulfobacter }\end{array}$ & g) Bacillus \\
\hline
\end{tabular}

\section{B Fe-cycling microorganisms in littoral freshwater sediment (Lake Constance)}

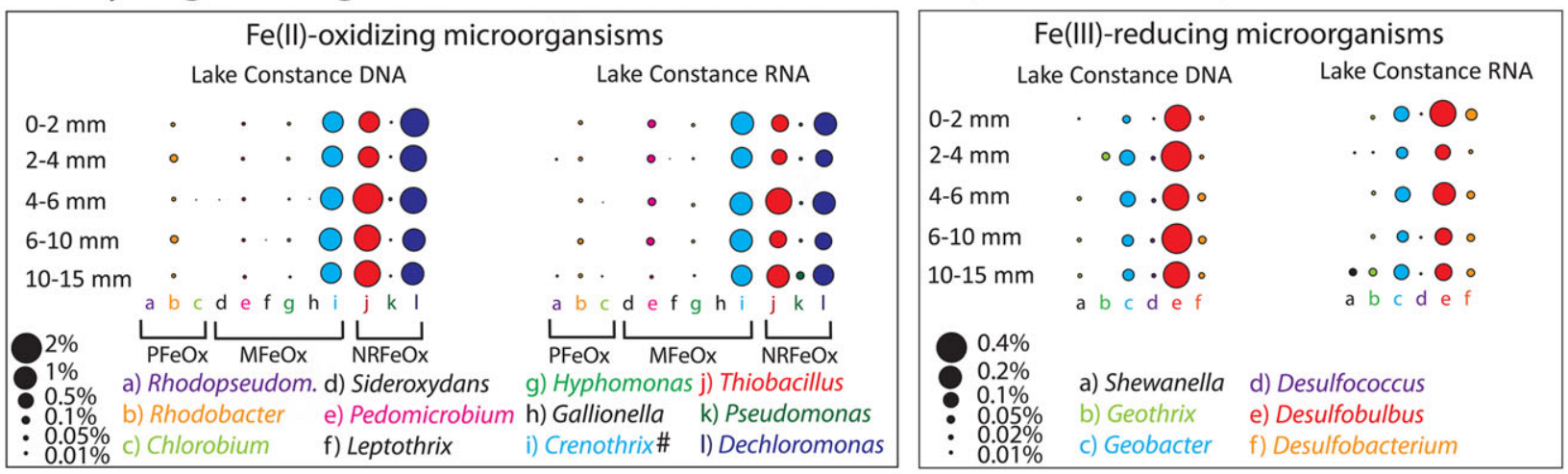

\section{Cable bacteria in marine sediments}

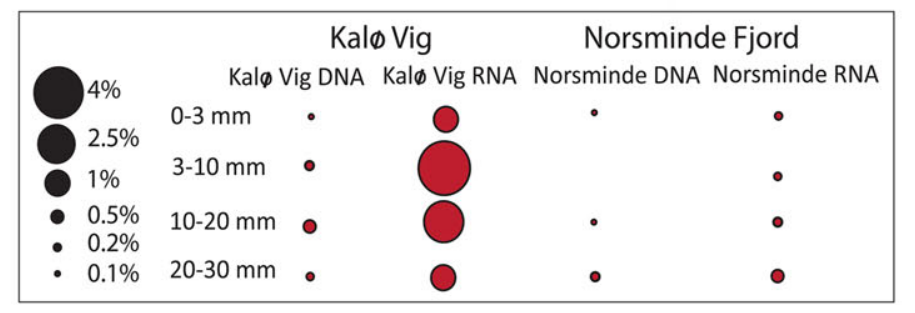

Fig. 1. Depth distribution and relative abundance of present and active Fe-metabolizing microorganisms in (A) coastal marine (Kalø Vig and Norsminde Fjord) and (B) littoral freshwater (Lake Constance) sediments.

A. Sediment layers: 0-3 mm, 3-10 mm, 10-20 mm, 20-30 mm; marine photoferrotrophs from Kalø Vig and Norsminde Fjord (up to 0.2\%); marine microaerophilic $\mathrm{Fe}(\mathrm{II})$-oxidizers (up to $0.1 \%$ ); marine NRFeOx (up to $0.2 \%$ ); marine Fe(III)-reducers from Norsminde Fjord and Kalø Vig (up to $2.8 \%$ ); cable bacteria in marine sediment (up to $2.5 \%$ ).

B. Freshwater Fe(II)-oxidizers from Lake Constance (0-2 mm, 2-4 mm, 4-6 mm, 6-10 mm, 10-15mm) (up to 2\%); freshwater Fe(III)-reducers from Lake Constance (up to $0.4 \%$ ).

C. Depth distribution and relative abundance of present and active cable bacteria in marine sediments (Kalø Vig and Norsminde Fjord). In Lake Constance sediment, the relative sequence abundance of cable bacteria is $<0.001 \%$ (data not shown).

\#: Crenothrix is most often associated with methanotrophy but there are also hints for Fe(II) oxidation. 


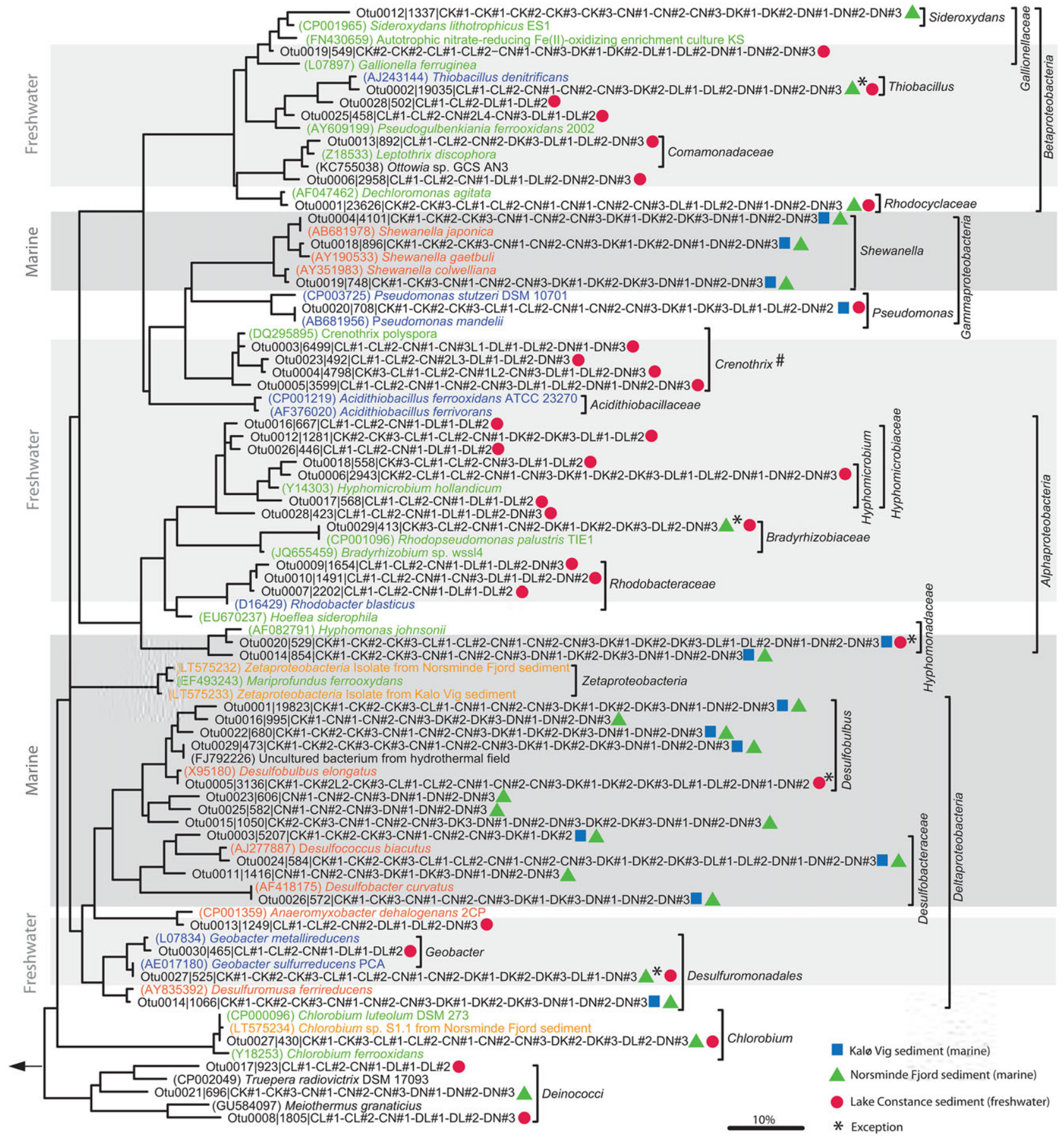

Fig. 2. Phylogenetic tree of most abundant (i.e., representing 30 most abundant OTUs respectively) Fe(II)-oxidizers and Fe(III)-reducers based on sequences obtained from Kalø Vig, Norsminde Fjord and Lake Constance sediments. Fe(II)-oxidizers are in green font, Fe(III)-reducers in red font, and bacteria which have the potential to oxidize and reduce Fe are in blue font. Recent Fe(II)-oxidizing isolated strains from Kalø Vig and Norsminde Fjord are in orange font. Symbols indicate sequences that appeared at specific field sites ( $\geq 15$ sequences). Boxes indicate marine sediment clusters (dark grey) and freshwater sediment clusters (light grey). *: Exceptions that they do not belong to the marked freshwater/marine site. " : Crenothrix is most often associated with methanotrophy but there are also hints for Fe(II) oxidation. A complete list of the taxa that were considered to harbour Fe-metabolizing strains can be found in the Supporting Information Table S4.

In Lake Constance freshwater sediments, PFeOx and $\mathrm{MFeOx}$ were low abundant $(<0.1 \%$; Fig. 1B). One exception was Crenothrix, which is most often associated with methanotrophy (Oswald et al., 2017) but there are also hints for Fe(II) oxidation (Rao et al., 2000; Emerson et al., 2010; Chen and Jiang, 2016; Demir, 2016). Crenothrix 


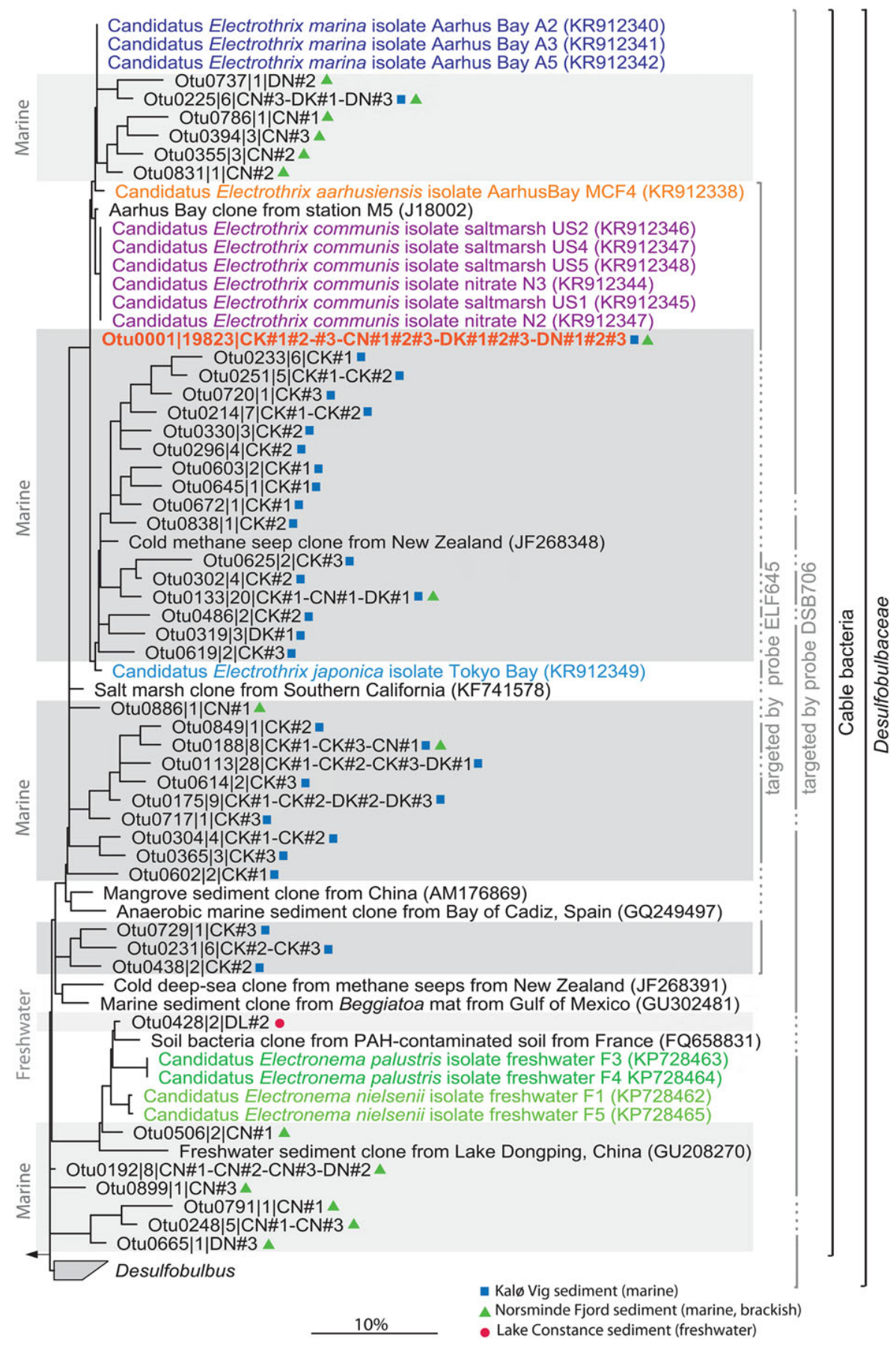

Fig. 3. Phylogenetic tree of cable bacteria related sequences obtained from Kalø Vig, Norsminde Fjord and Lake Constance. Described cable bacteria candidates are shown (freshwater candidates in green font; marine candidates in blue, purple and orange fonts, representing different species). The most abundant cable bacteria sequence from our study (OTU0001), shown in red font, is closely related to Electrothrix communis (purple font). Symbols indicate sequences that appeared at specific field sites ( $\geq 1$ sequences). Boxes indicate marine sediment clusters (dark grey) and freshwater sediment clusters (light grey). Grey clamps indicate sequences targeted by probes DSB706 and ELF645, typically used to identify cable bacteria via FISH. The solid lines of the clamps indicate a perfect probe match, whereas the dotted lines indicate at least one mismatch. was highly abundant (1.4\%) compared to other Fe(II)oxidizers and was found in all investigated sediment layers. The abundance of heterotrophic denitrifiers (e.g., Thiobacillus) and NRFeOx (e.g., Dechloromonas) were around $2 \%$ in the freshwater sediment respectively. Fe(III)-reducing bacteria affiliating with Geothrix, Geobacter and Shewanella showed relatively high abundance $(<0.4 \%)$ in the freshwater sediment.

\section{Diversity and relative abundance of cable bacteria}

Specific clusters of sequences affiliating with cable bacteria were detected at Norsminde Fjord, Kalø Vig and Lake Constance (Fig. 3). The existence of cable bacteria at the marine field sites was furthermore supported by representative OTU sequences that matched with oligonucleotide sequences of probes DSB706 and ELF645, typically used to identify cable bacteria via fluorescence in situ 
hybridization (FISH) (Fig. 3) and, in addition, by light microscopy (Supporting Information Fig. S5). The most abundant OTU, closely related to cable bacteria, was present in all layers of the three investigated sediment cores from Kalø Vig (based on DNA and RNA). This OTU shared $99.6 \%$ and $99.2 \%$ gene sequence identity with Candidatus Electrothrix communis and Candidatus Electrothrix japonica respectively (Fig. 3), and had relative abundances of $1-4.5 \%$ (Fig. 1C). In contrast, in Lake Constance and Norsminde Fjord sediments only between $0.001 \%$ and $0.4 \%$ of the sequences were related to cable bacteria.

\section{Vertical distribution of microbial groups and correlation with geochemical parameters}

Vertical distribution patterns in Kalø Vig sediment revealed that $56 \%$ of the OTUs were more abundant in the deeper sediment layers, $17 \%$ were more abundant in the surface sediment layers and $27 \%$ were homogenously distributed. In Norsminde Fjord sediment, $76 \%$ of OTUs were more abundant in the deeper sediment layers, $8 \%$ were more abundant in upper sediment layers and $16 \%$ were homogenously distributed. In Lake Constance sediment, $50 \%$ of OTUs were more abundant in deeper sediment layers, $25 \%$ were more abundant in upper sediment layers and $25 \%$ were homogenously distributed among sediment depth. Most of the vertical distribution patterns of the microbial groups (between $75 \%$ and $85 \%$ of microbial taxa) could, therefore, be explained by sediment depth and geochemical parameters such as oxygen, nitrate, sulfate and light. For example, sulfate-reducing bacteria affiliating with Desulfonema correlated significantly (Permanova, $P<0.0001)$ with depth at the marine sites, showing highest abundance (RNA: up to $0.04 \%)$ at greater depths (20$30 \mathrm{~mm}$ ) (Fig. 4A). Sequences affiliating with phototrophic Merismopedia (Cyanobacteria) in Norsminde Fjord sediment showed highest abundance (RNA: up to $5 \%$ ) at shallow depths $(0-3 \mathrm{~mm})$, while they were found to be less abundant (RNA: 1\%) at greater sediment depths (20$30 \mathrm{~mm}$ ) (Fig. 4A). In addition, members of the genus Pseudohaliea, that are strictly aerobic and typically found widespread in saline environments, correlated (Permanova, $P<0.0001$ ) with oxygen penetration, revealing highest abundances (RNA: up to $1.5 \%$ ) at $0-3 \mathrm{~mm}$ with a steep decrease down to $3 \mathrm{~cm}$ sediment depth at both marine sampling sites (Fig. 4A).

In contrast, $\mathrm{Fe}(\mathrm{III})$-reducers and $\mathrm{Fe}(\mathrm{II})$-oxidizers did not follow geochemical gradients, i.e., they were homogenously distributed with sediment depth and they did not correlate with any of the measured geochemical parameters (Figs. 1 and $4 \mathrm{~B}$ ). In addition, cable bacteria were almost completely homogenously distributed among sediment depths $(0.1 \%-$ $4.5 \%$; Fig. 1C) and showed a positive and significant $(F D R \leq 0.05)$ correlation with different parameters in Norsminde Fjord sediment (Supporting Information Table S6).
Summing up all $\mathrm{Fe}(\mathrm{II})$-oxidizer groups (i.e., $\mathrm{MFeOx}, \mathrm{PFeOx}$ and NRFeOx), a positive but not significant correlation to $\mathrm{Fe}(\mathrm{II})$ and $\mathrm{Fe}$ (III) concentrations was found (FDR $>0.5$ ). Similar to the marine sampling sites, Fe(III)-reducers and $\mathrm{Fe}$ (II) oxidizers showed no correlation with geochemical data in Lake Constance sediment (Supporting Information Table S6, Fig. S6).

\section{Correlations between Fe-cycling bacteria and cable bacteria}

To investigate interrelationships between active Fe-cycling bacteria and other active microbial groups, RNA-based distribution patterns were further explored for positive and negative correlations using the Spearman's rank (Supporting Information Table S6, Fig. S6). In the Kalø Vig sediment, a negative but not significant correlation between $\mathrm{Fe}$ (III)-reducers and $\mathrm{Fe}(\mathrm{II})$-oxidizers was found (Supporting Information Table S6). Surprisingly, in all investigated sediment layers of Kalø Vig sediment, a positive and highly significant $(\mathrm{FDR}<0.001)$ correlation was determined between cable bacteria and the group of $\mathrm{Fe}(\mathrm{III})$-reducers. Further analysis showed positive correlations between cable bacteria and most of the individual genera of known Fe(III)-reducers such as Desulfovibrio, Desulfococcus and Geobacter, though not significant (FDR $\leq 0.8$; Supporting Information Fig. S6). In addition, the correlation between cable bacteria and most of the single $\mathrm{Fe}(\mathrm{II})$-oxidizing populations such as Pedomicrobium and Hoeflea was also positive in Kalø Vig sediment $(F D R<0.8)$. In the sediment from Norsminde Fjord, a positive correlation between $\mathrm{Fe}$ (III)-reducers and $\mathrm{Fe}$ (II)-oxidizers was found. Similar to the trends observed in the Kalø Vig results, a positive correlation between cable bacteria and $\mathrm{Fe}$ (III)-reducers was detected. In particular, the $\mathrm{Fe}$ (III)-reducers affiliating with Desulfovibrio and Geobacter showed a positive correlation $(F D R=0.12$ and 0.42$)$ with the cable bacteria. Furthermore, the correlation between cable bacteria and $\mathrm{Fe}(\mathrm{II})$-oxidizers (i.e., the $\mathrm{PFeOx}$ Chlorobium and Rhodopseudomonas) was positive (FDR $<0.5)$. In Lake Constance freshwater sediment, a positive but not significant correlation between $\mathrm{Fe}$ (III)-reducers and $\mathrm{Fe}$ (II)-oxidizers was found (Supporting Information Table S6) but there was no correlation between cable bacteria and $\mathrm{Fe}$ (II)-oxidizers or $\mathrm{Fe}(\mathrm{III})$-reducers respectively. In summary, significant $(\mathrm{FDR}<0.05)$ correlations were found for $\mathrm{Fe}(\mathrm{III})$-reducers and cable bacteria, particularly for the field sites with high abundances of active cable bacteria (i.e., Kalø Vig).

\section{Discussion}

Significance of neutrophilic Fe-cycling bacteria in low-iron freshwater and marine sediments

The low-iron field sites from our study are widely representative for typical marine and freshwater habitats. At all field 


\section{A Relative sequence distribution of selected microbial taxa in marine sediment (e.g. Norsminde Fjord)}
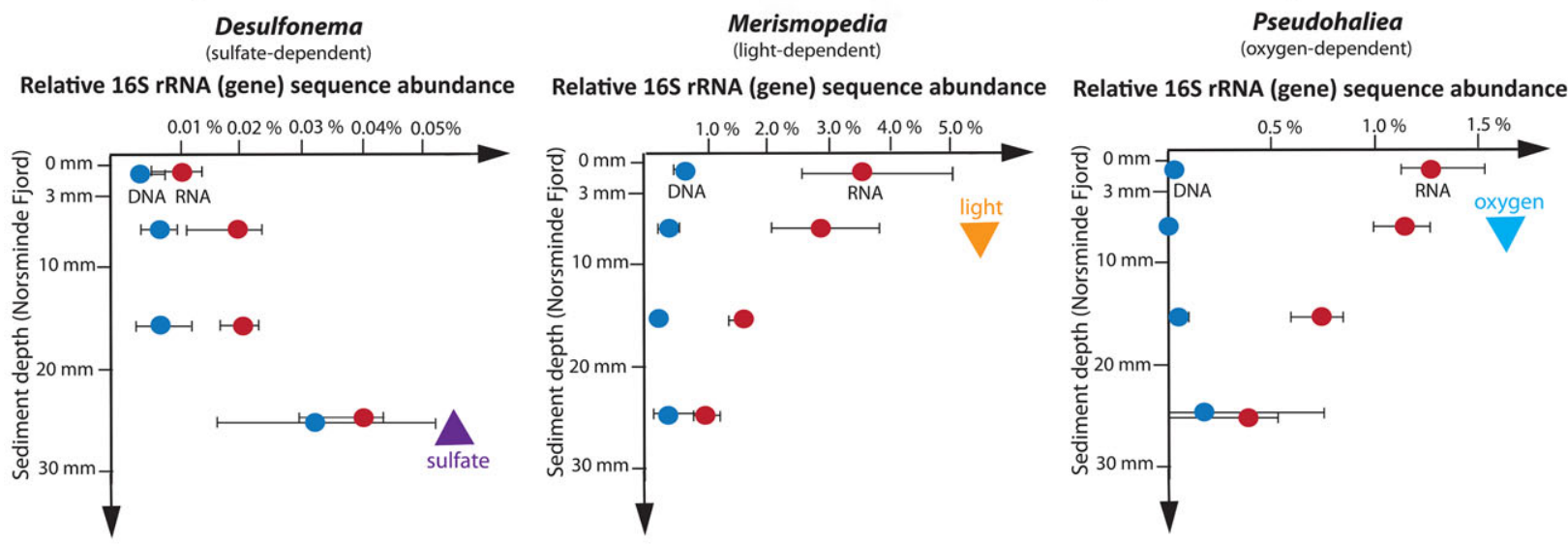

B Schematic illustration of relative sequence distribution of $\mathrm{FeO} x$ and FeRed in marine and freshwater sediment

Expected 16S rRNA (gene) sequence abundance Relative $16 \mathrm{~S}$ rRNA (gene) sequence abundance

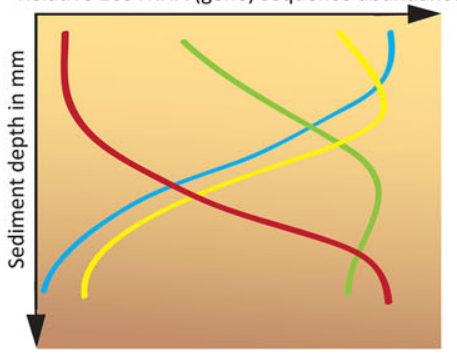

Detected 16S rRNA (gene) sequence abundance Relative 16S rRNA (gene) sequence abundance

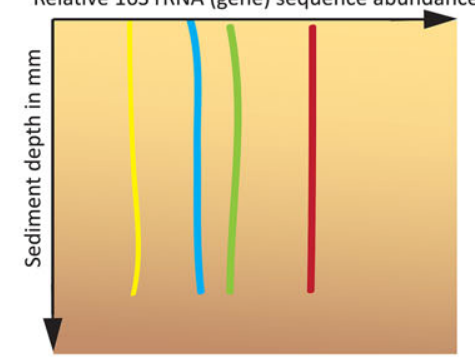

Geochemical gradients

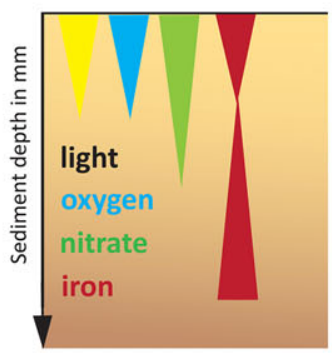

Legend

PFeOx

MFeOXOC

NRFeOX

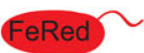

Fig. 4. A. Relative sequence distribution of selected microbial taxa in marine sediment at Norsminde Fjord. Selected bacterial distribution patterns following sediment depth and geochemical parameters, such as sulfate, light and oxygen. Relative sequence abundances of the 16S rRNA (gene) are shown based on DNA (blue circles) and RNA (red circles) analyses respectively.

B. Schematic illustration of relative sequence distribution of Fe(II)-oxidizers and Fe(III)-reducers in marine and freshwater sediment; PFeOx in orange, $\mathrm{MFeOx}$ in blue, NRFeOx in green and $\mathrm{Fe}(\mathrm{III})$-reducers in red colour.

sites, diverse, active Fe-cycling bacteria (MFeOx, PFeOx, NRFeOx and $\mathrm{Fe}(\mathrm{III})$-reducing bacteria) were identified based on taxonomy. However, using taxonomy to infer metabolic functions is challenging, thus, some of the Femetabolizing taxa identified in this study may perform different metabolic functions in situ. Comparing the relative abundance among Fe-cycling bacteria at our field sites, active $\mathrm{Fe}$ (III)-reducers were more abundant but might be overestimated because of their metabolic flexibility (iron and sulfate reduction), while less abundant active $\mathrm{Fe}$ (II)oxidizers might be underestimated since many $\mathrm{Fe}(\mathrm{II})$-oxidizers might currently be uncultured and, therefore, remain unexplored. Albeit detected in low abundance, as also previously shown (Berg et al., 2016; Laufer et al., 2016), Femetabolizers can have a substantial impact on important biogeochemical cycles, such as carbon, sulfur and nitrogen, thereby influencing the fate of contaminants and greenhouse gases (Canfield, 1989; Borch et al., 2010; Picardal, 2012; Buchwald et al., 2016). Furthermore, Fe metabolizers might be actively involved in 'cryptic element cycles', which may lead to a rapid turnover (Kappler and
Bryce, 2017), indicating that $\mathrm{Fe}(\mathrm{II})$-oxidizers and $\mathrm{Fe}(\mathrm{III})$ reducers are crucial in low-iron environments.

\section{Neutrophilic Fe-cycling bacteria were decoupled from geochemical gradients}

Based on the microbial redox 'tower', aerobic respiration, denitrification, manganese(IV) reduction, Fe(III) reduction, sulfate reduction and methanogenesis are thought to proceed in a sequence, determined by thermodynamics, i.e., the energy yield of the different reactions (Richards, 1965; Froelich et al., 1979; Orcutt et al., 2011), creating typical geochemical gradients. However, in the environment, different metabolic processes were found to be co-occurring in the same sediment zone (Chen et al., 2017a; Giling et al., 2017). At our field sites, the vertical distribution of most active microbial groups correlated with measured geochemical gradients, while active Fe-metabolizing bacteria were decoupled from these gradients, which was highly unexpected. Since, our marine and freshwater field sites provided favourable conditions for all three metabolic 
types of $\mathrm{Fe}(\mathrm{II})$-oxidizers and of $\mathrm{Fe}(\mathrm{III})$-reducers, it was hypothesized that their in situ abundances, especially of active populations (i.e., based on RNA sequences), would follow gradients of light, oxygen, nitrate and iron (Fig. 4). In contrast, we found homogeneously distributed abundances of present and active $\mathrm{Fe}(\mathrm{II})$-oxidizers and $\mathrm{Fe}(\mathrm{III})$ reducers in marine and freshwater sediments (Figs. 1 and 4). Our findings are supported by a previous study which demonstrated homogeneously distributed abundances of $\mathrm{Fe}(\mathrm{II})$-oxidizers based on cultivation-dependent most probable number experiments (Laufer et al., 2016) and of Zetaproteobacteria based on qPCR assays (Laufer et al., 2016). While the actual reason for an uncoupling of Fecycling bacteria and geochemical gradients remains currently unresolved, there are several possible explanations, including physical mixing, motility, dormancy, microniches, metabolic flexibility, or interactions with cable bacteria.

Physical mixing might be caused by macrofauna (e.g., polychaetes and crustaceans), tidal activity, wind, or human activity (Laufer, 2016; Chen et al., 2017b) and might impact the distribution of Fe(II)-oxidizers and Fe(III)reducers. Bioturbation by burrowing fauna is well known from the upper 6-8 cm of Aarhus Bay sediments (Thamdrup et al., 1994). In addition, a storm event in Norsminde Fjord showed a strong influence on geochemical gradients (e.g., oxygen, $\mathrm{pH}$, redox potential and sulfide) (Laufer, 2016). However, in our study, the majority of microbial groups followed geochemical gradients and, thus, physical mixing might be a minor reasons for the homogeneous distribution of Fe-metabolizers.

Motile microorganisms might move towards favourable conditions (Thar and Fenchel, 2005; Krepski et al., 2012) or microorganisms might enter a dormant state with a slow metabolism, without growth and cell division, until conditions become favourable. To date, only certain Fe(II)oxidizers and Fe(III)-reducers were found to be motile, e.g., Shewanella oneidensis, Rhodopseudomonas palustris and Mariprofundus ferrooxydans (Jiao et al., 2005; Wu et al., 2011; Laufer et al., 2017). It remains further unknown to which extent Fe(II)-oxidizers and Fe(III)-reducers switch into a dormant mode or enter a dormant state in the environment.

Metabolic flexibility is well-known for NRFeOx, PFeOx and $\mathrm{Fe}(\mathrm{III})$-reducers expanding their possible niches. For example, NRFeOx might be able to perform microaerophilic $\mathrm{Fe}(\mathrm{II})$ oxidation or even growth with oxygen on organic carbon (Benz et al., 1998; Edwards et al., 2003; Weber et al., 2006b). Furthermore, PFeOx may grow heterotrophically under oxic conditions (Straub et al., 1999; Jiao et al., 2005; Melton et al., 2014a; Thompson et al., 2017), live chemolithoautotrophically on hydrogen or reduced sulfur species, or photoheterotrophically on organic carbon (Widdel et al., 1993; Heising et al., 1999; Straub et al., 1999; Thompson et al., 2017). Some Fe(III)- reducers may grow heterotrophically with oxygen, while others can live on fermentation (Lovley, 2006; Klueglein et al., 2014; Ehrlich et al., 2015). In addition, Fe(III)-reducers may oxidize $\mathrm{Fe}(\mathrm{II})$ with nitrate (Finneran et al., 2002; Weber et al., 2006a) or perform sulfate reduction. Therefore, it is possible that potential Fe-cycling microorganisms in the environment are metabolically flexible and capable of utilizing electron acceptors or donors, in addition or instead of $\mathrm{Fe}(\mathrm{III})$ and $\mathrm{Fe}(\mathrm{II})$.

Since active Fe-metabolizing microorganisms were found to co-exist, there are opportunities for their interaction and competition with each other, for example, to obtain electrons from $\mathrm{Fe}(\mathrm{II})$ or to use $\mathrm{Fe}(\mathrm{III})$ as electron acceptor (Melton et al., 2012). Furthermore, most microorganisms may live in microniches, where they have access to electron acceptors that might be below detection of our analysis (Jørgensen, 1977; Lehto et al., 2014). This in turn may cause ecological niches to overlap, leading to competition or cooperation of Fe-metabolizers.

Hypothetical interplay of Fe-metabolizing microorganisms and cable bacteria

Interaction between Fe-metabolizing bacteria with cable bacteria, i.e., multicellular structures which have the ability to transport electrons over a long distance in sediments (Nielsen et al., 2010; Pfeffer et al., 2012), might be another explanation for the homogenous distribution of Fe-cycling bacteria (Fig. 5A). Previous studies showed evidence for a potential influence of cable bacteria on Fe-cycling bacteria in sediments (Seitaj et al., 2015), however, their coexistence has not been studied so far. Here, we provide direct evidence for the co-existence of active cable bacteria and Fe-metabolizing bacteria in marine sediments (Fig. $5 \mathrm{~B}$ ), indicating that the activity of cable bacteria might be another reason for the observed decoupling of Fe-cycling microorganisms from geochemical gradients. Albeit thirdparty factors influencing the distribution patterns of microbial populations cannot be ruled out, the positive correlation of Fe-cycling bacteria with cable bacteria could be a first indicator of a causal interrelationship between both populations.

Several hypothetical scenarios could explain potential interrelationships between Fe-cycling bacteria and cable bacteria. It is known that cable bacteria oxidize sulfide with oxygen, but also use nitrate and nitrite as electron acceptors (Risgaard-Petersen et al., 2012; Marzocchi et al., 2014) (Fig. 6A). Furthermore, it was suggested that electrogenic oxidation processes, i.e., the coupling of the oxidation and the reduction step of a redox reaction via long-distance electron transport, seems to not only rely on sulfide but could also depend on other donors such as organic compounds, fatty acids, Fe(II), or methane. However, sulfate reduction rates might be sufficient to support 


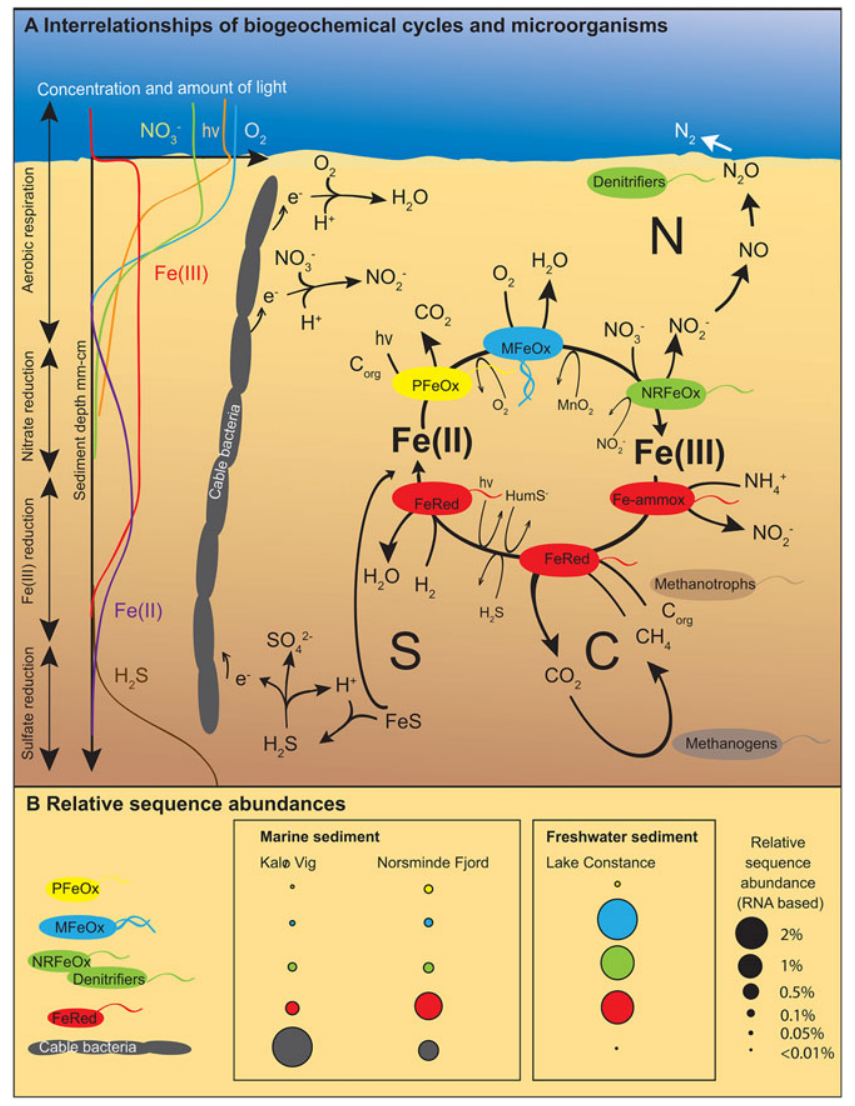

Fig. 5. A. Interrelationships of biogeochemical cycles and microbial activities in marine and freshwater sediments. Geochemical gradients of light, oxygen, nitrate, $\mathrm{Fe}(\mathrm{II}), \mathrm{Fe}(\mathrm{III})$ and $\mathrm{H}_{2} \mathrm{~S}$ are illustrated. The Fe cycle is mediated by phototrophic $\mathrm{Fe}(\mathrm{II})$-oxidizers (PFeOx, yellow), microaerophilic Fe(III)-oxidizers (MFeOx, blue), nitrate-reducing Fe(II)-oxidizers (NRFeOx, green) and Fe(III)-reducing bacteria (FeRed, red) and coupled to anammox-bacteria performing Fe(III) reduction. The Fe cycle is linked to the nitrogen cycle and formation of the greenhouse gas $\mathrm{N}_{2} \mathrm{O}$.

B. Relative sequence abundances of microorganisms in marine and freshwater sampling sites (averaged per physiological group, among sediment depths and replicate cores). Relative sequence abundance (RNA-based) of MFeOx: $0.07 \%$ in Kalo Vig (KV), $0.1 \%$ in Norsminde Fjord (NS), 2.3\% in Lake Constance (LC); denitrifiers and potential NRFeOx: $0.1 \%$ (KV), $0.3 \%$ (NS), $2.2 \%$ (LC); PFeOx: $0.002 \%$ (KV), $0.2 \%$ (NS), $0.06 \%$ (LC); FeRed: $0.3 \%$ (KV), $1.2 \%$ (NS), $1.6 \%$ (LC); cable bacteria: $2.5 \%(\mathrm{KV}), 0.8 \%(\mathrm{NS}), 0.2 \%$ (LC).

the activities of cable bacteria in these sediments (Nielsen and Risgaard-Petersen, 2015; Risgaard-Petersen et al., 2015). Therefore, if cable bacteria were able to take up electrons from $\mathrm{Fe}(\mathrm{II})$, thus oxidizing the $\mathrm{Fe}(\mathrm{II})$ to $\mathrm{Fe}(\mathrm{III})$, there might be potential competition with all three physiological types of $\mathrm{Fe}(\mathrm{II})$-oxidizing bacteria (Fig. 6B). Furthermore, this may lead to a cooperation with $\mathrm{Fe}(\mathrm{III})$ reducing bacteria that can re-reduce the $\mathrm{Fe}$ (III) produced by the cable bacteria, thus providing more $\mathrm{Fe}$ (II) for the cable bacteria. This potential stimulation of $\mathrm{Fe}$ (III)-reducers by the cable bacteria, however, may also fuel the activity of $\mathrm{Fe}(\mathrm{II})$-oxidizers by the available $\mathrm{Fe}(\mathrm{II})$. And indeed, both $\mathrm{Fe}$ (II)-oxidizers and $\mathrm{Fe}$ (III)-reducers showed positive and significantly positive correlations with cable bacteria respectively, suggesting a possible cooperation and a potential for direct interspecies electron transfer (DIET) between $\mathrm{Fe}(\mathrm{II})$-oxidizers, $\mathrm{Fe}$ (III)-reducers and cable bacteria (Rotaru et al., 2014) (Fig. 6B). This could lead to a localized cryptic Fe-cycle that requires relatively small amounts of $\mathrm{Fe}$ and that would not be observable by significant accumulations of $\mathrm{Fe}(\mathrm{III})$ oxyhydroxides (Kappler and Bryce, 2017), confirming our geochemical Fe data in the sediments.

Recently, it was mentioned that the long-distance electron transport by cable bacteria and a counter-ion diffusion in the marine sediment, is forming a kind of 'biogeobattery' (Revil et al., 2010; Risgaard-Petersen et al., 2012; Nielsen and Risgaard-Petersen, 2015). Such a biogeobattery system would allow the microbial community including the $\mathrm{Fe}$ metabolizing microorganisms to be independent of substrate availability which indicates that Fe-oxidizing bacteria may donate electrons to the cable bacteria or Fe(III)-reducing bacteria may use the cables as an ' $e$-power line' to take up electrons (Fig. 6C). Therefore, the electrogenic multistep sulfur oxidation might be performed by a microbial consortium ('swarming e-community' surrounding the 


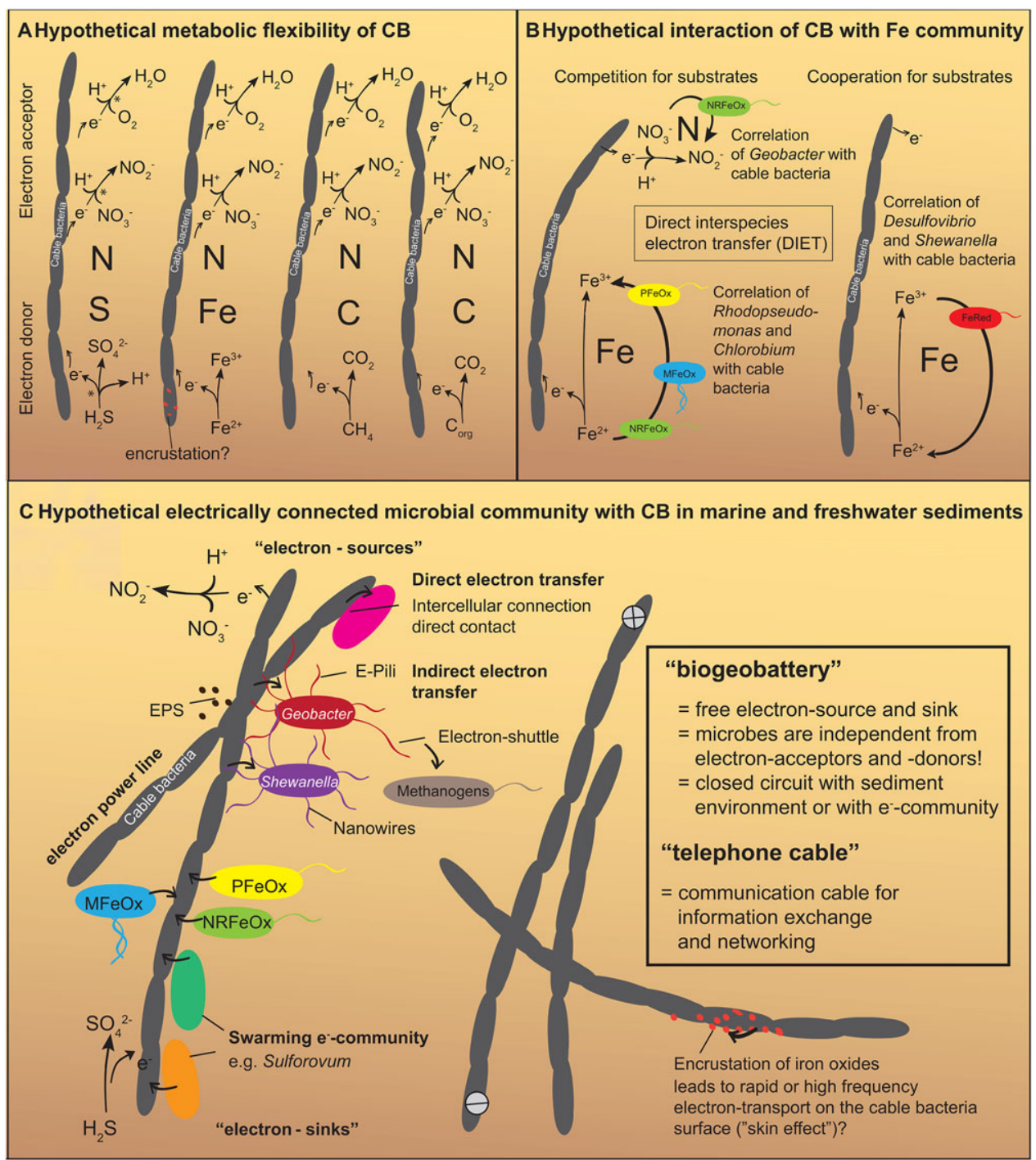

Fig. 6. A. Hypothetical models of the potential metabolic flexibility of cable bacteria based on Risgaard-Petersen et al. (2015). Coupling of sulfide oxidation to cable bacteria (marked with an asterisk; *) has been observed (Pfeffer et al., 2012). All other models are hypothetical. B. Hypothetical models of the potential connection and interaction of cable bacteria with Fe-cycling bacteria. If cable bacteria reduce nitrate as electron acceptor there might be a competition with nitrate-reducing $\mathrm{Fe}(\mathrm{II})$-oxidizers (NRFeOx) bacteria. If cable bacteria have the metabolic flexibility to also oxidize $\mathrm{Fe}$ (II) there might be potential competition with all physiological types of $\mathrm{Fe}(\mathrm{II})$-oxidizing microorganism. Conversely, there could also be a cooperation of Fe(III)-reducing microorganisms like Geobacter and Desulfovibrio producing Fe(II) for the potential metabolically flexible Fe(II)-oxidizing cable bacteria.

C. Hypothetical models of the potential electrically connected microbial community in marine and freshwater sediments. In case of the absence of an electron acceptor, the 'swarming $\mathrm{e}^{-}$community' might donate electrons to the cable bacteria or they might use the cables as an ' $e$-power line' to take electrons. The significant positive correlation between some Fe-cycling bacteria and cable bacteria suggests a potential cooperation and network system in the marine and freshwater sediments. The current-forming microbial community might create a kind of 'biogeobattery'. Such a biogeobattery system would allow the microbial community to be independent of substrate availability suggesting that the presence of all Fe-metabolizing microorganisms in all upper sediment layers might be based on the occurrence of sulfide-oxidizing cable bacteria communities. Cable bacteria might be essentially functioning as telephone cables in the sea floor. Therefore, the microbial communities might share information as well as energy through their electrical connections. CB indicates cable bacteria.

cable bacteria) of Epsilon- and Gammaproteobacteria like Sulfurimonas, Sulforovum, Heliobacter, Arcobacter, Parabeggiatoa and Thiomicrospira (Vasquez-Cardenas et al., 2015; Lovley, 2017) from which the Fe-cycling bacteria might benefit through DIET. A recent study revealed that
PFeOx (e.g., Rhodopseudomonas palustris TIE1) are able to use extracellular electron transfer for electron uptake (Bose et al., 2014; Byrne et al., 2015), supporting that $\mathrm{Fe}(\mathrm{II})$-oxidizers might belong to the potential electrogenic community. We found that potential electrogenic 
community members such as Sulforovum and Helibacter were among the most abundant genera in our marine sediments (Supporting Information Table S2), suggesting that Fe-metabolizing bacteria and additional community members may benefit from the electron transport by cable bacteria.

A possible additional mechanism by which $\mathrm{Fe}$ (II)-oxidizing bacteria might benefit from cable bacteria is that, in suboxic zones, the activity of cable bacteria promotes dissolution of $\mathrm{Fe}$ sulfides, leading to upwards $\mathrm{Fe}$ (II) diffusion and to the production and precipitation of $\mathrm{Fe}$ oxides in the oxic zone (Risgaard-Petersen et al., 2012; Rao et al., 2016; Sulu-Gambari et al., 2016) which may also form precipitates around the cable bacteria (personal communication with Nicole Geerlings, Utrecht University). The Fe precipitates around the cable bacteria may result in electrons not only flowing in the periplasm of the cable bacteria but also on the surface of the cables (Fig. $6 \mathrm{C}$ ). This coating may lead to a rapid electron flow or a highfrequency electron transport on the cable bacteria surface ('electrical skin effect') (Lamb, 1883; Heaviside, 1885; Wheeler, 1942; Haines, 1959; Kim et al., 2017), suggesting a fast communication system within the sediments. Recently, it was proposed that electricity-generating cable bacteria are essentially functioning as telephone cables in the sea floor (Malkin and Meysman, 2015). Therefore, the microbial communities (including Fe-metabolizers) at our field sites might share information as well as energy through their electrical connections (Lovley, 2017) (Fig. 6C).

\section{Conclusions}

Our study demonstrated the co-existence of active Fe(II)oxidizing and $\mathrm{Fe}(\mathrm{III})$-reducing microorganisms in sediments that are widely representative of typical marine and freshwater environments. Metabolic flexibility of $\mathrm{Fe}$ metabolizers, microniches in the sediments, and the activity of cable bacteria might be reasons for the observed uncoupling of the distribution of Fe-cycling bacteria from geochemical gradients. However, it remains to be explored whether cable bacteria might be, directly or indirectly, involved in $\mathrm{Fe}(\mathrm{II})$ oxidation or $\mathrm{Fe}$ (III) reduction and if $\mathrm{Fe}$ metabolizing bacteria and other members of the microbial community interact with cable bacteria in marine and freshwater sediments.

\section{Experimental procedures}

Site description, sampling procedure and geochemical analyses

Marine sediment samples were taken in July 2015 from two field sites in the Aarhus Bay area (Denmark). Sediment from the shallow marine estuary Norsminde Fjord (NS), was collected at $0.5 \mathrm{~m}$ water depth near its narrow entrance from Aarhus Bay (N 56 01.171'; E 010 15.390'). Samples from the second marine field site, Kalø Vig (KV) (N 56 16.811'; E $010^{\circ} 28.056^{\prime}$ ), a shallow lagoon with organic-poor sandy sediment, were collected at 0.5-1 m water depth. Freshwater sediment samples were taken in September 2015 from Ueberlingersee close to the island of Mainau in the northwestern part of Lake Constance (LC) (N47 41.710'; E9 ${ }^{\circ} 11.671^{\prime}$ ) southern Germany, at $0.5 \mathrm{~m}$ water depth. All sediment samples from marine and freshwater sediments were collected with push-cores, $2.5 \mathrm{~cm}$ in diameter (cut-off $50 \mathrm{ml}$ syringes). Push-cores were taken in close proximity to each other $(\sim 1 \mathrm{~m})$ in triplicates or duplicates for marine and freshwater sediments respectively (Supporting Information Fig. S7), and preserved as described in the supporting information. Temperature, $\mathrm{pH}$, salinity and oxygen concentration of the water column were analysed in the field with a multimeter (WTW, Multi 3430). The geochemical gradients of oxygen, redox potential, $\mathrm{pH}$ and sulfide were directly measured on site at in situ temperatures at $0.5 \mathrm{~mm}$ depth intervals using microelectrodes (UniSense), while we used different microelectrodes for Aarhus Bay and Lake Constance sampling trips. All geochemical analyses are described in detail by Laufer and colleagues (2016).

DNA/RNA extraction, DNA digestion, reverse transcription, quantitative PCR of $16 S$ rRNA (genes) and 16S rRNA (gene) amplicon sequencing

Total DNA and RNA was extracted using the PowerSoil ${ }^{\circledR}$ RNA and DNA isolation kit as directed by the manufacturer (MO BIO Laboratories, Carlsbad, CA, USA), with the following modifications: $0.8 \mathrm{~g}$ to $2 \mathrm{~g}$ sediment was used from each sediment slice; 5 min bead-beating; centrifugation steps at maximal speed $(7000 \times \mathrm{g})$ at $4^{\circ} \mathrm{C}$; and longer incubation times at $-20^{\circ} \mathrm{C}(1.5-2.0 \mathrm{~h})$. RNA and DNA were eluted in $50 \mu \mathrm{l}$ $10 \mathrm{mM}$ Tris buffer. DNA and RNA concentrations were determined using a Qubit ${ }^{\circledR}$ 2.0 Fluorometer with DNA and RNA HS kits (Life Technologies, Carlsbad, CA, USA). Subsequent DNA digestion and reverse transcription reactions were done using a Reverse Transcriptase (Invitrogen, Life Technologies), as described in the supporting information.

Quantitative PCR (qPCR) specific for the 16S rRNA (gene) of bacteria and archaea was performed using an iQ5 real-time PCR detection system (iQ5 optical system software, version 2.0, Bio-Rad). Plasmid standards, gene-specific qPCR primers, reaction mixtures and thermal programs are given in the supporting information.

Microbial 16S rRNA (genes) were amplified using primers $515 \mathrm{~F}$ and 806R (Caporaso et al., 2010) targeting the V4 region as described in the supporting information. The produced amplicons were purified using AMPure XP beads (Beckman Coulter, Brea, CA, USA) at a ratio of 0.8:1 (v/v). Quality and quantity of the purified amplicons were determined using agarose gel electrophoresis and Nanodrop (NanoDrop 1000, Thermo Scientific, Waltham, MA, USA). Subsequent library preparation steps and sequencing were performed by IMGM Laboratories $\mathrm{GmbH}$ (Martinsried, Germany) using an Illumina MiSeq sequencing system (Illumina, San Diego, CA, USA), as described in the supporting information. Primer-trimmed reads (accession number: SRP111913) 
have been deposited in the NCBI Genbank database (bioproject: PRJNA393823).

\section{Sequence analysis}

Quality control of raw 16S rRNA read pairs was performed using Cutadapt v1.9 (Martin, 2011) and USEARCH v8.1.1812 (Edgar and Flyvbjerg, 2015), as described in the supporting information. Quality filtered sequences were imported in MOTHUR (1.35.1) (Schloss et al., 2009) and analysed according to Kozich et al. (2013), as described in the supporting information. A distance matrix was created and operational taxonomic units (OTUs) were clustered at $3 \%$ genetic distance using the average neighbour algorithm (Schloss et al., 2011). Sequences were classified using the Naive Bayesian Classifier (Wang et al., 2007) and the SILVA database (SSURef NR99 119). Random subsampling was performed to normalize the data set to the sample with the lowest number of reads (i.e., 25796 reads). Rarefaction curves, diversity indices (Shannon diversity, Simpson diversity), richness (Chao1, ACE) and coverage estimators (Good's coverage) were calculated using MOTHUR (Supporting Information Table S1).

\section{Phylogenetic analysis}

16S rRNA (gene) sequences were aligned using SINA (Pruesse et al., 2012). Phylogenetic analyses of 16S rRNA (gene) sequences were conducted with the ARB software package (Ludwig et al., 2004) and the database SSURef NR99 119 from ARB SILVA (Pruesse et al., 2007). Phylogenetic trees were calculated by maximum-likelihood method (PhyML) using full-length sequences. Partial sequences, i.e., representative OTU sequences, were inserted into the tree by parsimony criteria without allowing changes in the overall tree topology. Sequences classified as cable bacteria were further analysed using the probe match function implemented in ARB. Probe matches were conducted for probes DSB706 (5'ACCGGTATTCCTCCCGAT-3') (Loy et al., 2002; Lücker et al., 2007) and ELF645 (5'-CCTCTGATACTCAAGCCAAG-3') (Pfeffer et al., 2012).

\section{Statistical analysis}

Statistically significant differences $(P<.05 ; P<.001)$ among the relative sequence abundance of bacterial 16S rRNA (genes) were determined using STAMP (v2.0.8) (Parks et al., 2014) applying multiple group tests (PCoA and ANOVA), described in the supporting information. Sequencing data were further explored using the PRIMER software (version 7.0.11; Primer-E, Plymouth, UK) with the PERMANOVA+ add on to compare DNA (present community) and RNA (active community), as described in the supporting information. Spearman's rank correlation coefficient and multiple testing correction (Supporting Information Table S6 and Fig. S6) between active microbial groups (e.g., RNA-based Fe-cycling microorganisms and cable bacteria sequences of OTU0001; see Fig. 3) and geochemical data were determined as described in the supporting information.

\section{Acknowledgements}

We thank Franziska Schädler for sharing unpublished information on freshwater Fe(II)-isolates as well as Karin Stögerer (deceased), Wiebke Ruschmeier, Dr. Pascal Weigold and Kalen Rasmussen for the help in the laboratory and for assistance in the field as well as Jesper T. Bjerg (University of Aarhus) for light microscopy images. We are also grateful to Saskia Rughöft, Dr. Jing He, Dr. Casey Bryce (University of Tübingen), Prof. Ralf Otte (University of Ulm) and Nicole Geerlings (University of Utrecht) for helpful discussions and comments. We additionally thank Prof. Ivan Berg (University of Münster) for providing archaeal DNA for the MOCK culture. This project was supported by the European Research Council under the European Union's Seventh Framework Program (FP/2007-2013)/ERC Grant, agreement no. 307320MICROFOX. S.K. is supported by an Emmy-Noether fellowship (grant \# 326028733) from the German Research Foundation (Deutsche Forschungsgemeinschaft, DFG).

\section{Conflict of Interest}

The authors declare no conflict of interest.

\section{References}

Benz, M., Brune, A., and Schink, B. (1998) Anaerobic and aerobic oxidation of ferrous iron at neutral $\mathrm{pH}$ by chemoheterotrophic nitrate-reducing bacteria. Arch Microbiol 169: 159-165.

Berg, J.S., Michellod, D., Pjevac, P., Martinez-Perez, C., Buckner, C.R., and Hach, P.F. (2016) Intensive cryptic microbial iron cycling in the low iron water column of the meromictic Lake Cadagno. Environ Microbiol 18: 52885302.

Blöthe, M., and Roden, E.E. (2009) Microbial iron redox cycling in a circumneutral-pH groundwater seep. Appl Environ Microb 75: 468-473.

Borch, T., Kretzschmar, R., Kappler, A., Cappellen, P.V., Ginder-Vogel, M., Voegelin, A., and Campbell, K. (2010) Biogeochemical redox processes and their impact on contaminant dynamics. Environ Sci Technol 44: 15-23.

Bose, A., Gardel, E., Vidoudez, C., Parra, E., and Girguis, P. (2014) Electron uptake by iron-oxidizing phototrophic bacteria. Nat Commun 5: 3391.

Bruun, A.-M., Finster, K., Gunnlaugsson, H.P., N $\oslash$ Rnberg, P., and Friedrich, M.W. (2010) A comprehensive investigation on iron cycling in a freshwater seep including microscopy, cultivation and molecular community analysis. Geomicrobiology Journal 27: 15-34.

Buchwald, C., Grabb, K., Hansel, C.M., and Wankel, S.D. (2016) Constraining the role of iron in environmental nitrogen transformations: Dual stable isotope systematics of abiotic $\mathrm{NO}_{2}^{-}$reduction by $\mathrm{Fe}$ (II) and its production of $\mathrm{N}_{2} \mathrm{O}$. Geochim Cosmochim Ac 186: 1-12.

Byrne, J.M., Klueglein, N., Pearce, C., Rosso, K.M., Appel, E., and Kappler, A. (2015) Redox cycling of Fe (II) and Fe (III) in magnetite by Fe-metabolizing bacteria. Science 347 : 1473-1476.

Canfield, D.E. (1989) Reactive iron in marine sediments. Geochim Cosmochim Ac 53: 619-632. 
Canfield, D.E., Thamdrup, B., and Hansen, J.W. (1993) The anaerobic degradation of organic matter in Danish coastal sediments: iron reduction, manganese reduction, and sulfate reduction. Geochim Cosmochim Ac 57: 3867-3883.

Caporaso, J.G., Kuczynski, J., Stombaugh, J., Bittinger, K., Bushman, F.D., Costello, E.K., et al. (2010) QIIME allows analysis of high-throughput community sequencing data. Nat Methods 7: 335-336.

Chen, J., Hanke, A., Tegetmeyer, H.E., Kattelmann, I., Sharma, R., and Hamann, E. (2017) Impacts of chemical gradients on microbial community structure. Isme $J$ 11: 920.

Chen, M., and Jiang, H.-L. (2016) Relative contribution of iron reduction to sediments organic matter mineralization in contrasting habitats of a shallow eutrophic freshwater lake. Environ. Pollut 213: 904-912.

Chen, X., Andersen, T.J., Morono, Y., Inagaki, F., Jørgensen, B.B., and Lever, M.A. (2017) Bioturbation as a key driver behind the dominance of Bacteria over Archaea in nearsurface sediment. Sci. Rep 7: 2400.

Chiu, B.K., Kato, S., McAllister, S.M., Field, E.K., and Chan, C.S. (2017) Novel pelagic iron-oxidizing zetaproteobacteria from the Chesapeake bay oxic-anoxic transition zone. Front Microbiol 8: 1280.

Demir, N.M. (2016) Experimental study of factors that affect iron and manganese removal in slow sand filters and identification of responsible microbial species. Pol J Environ Stud 25: 1453.

Edgar, R.C., and Flyvbjerg, H. (2015) Error filtering, pair assembly and error correction for next-generation sequencing reads. Bioinformatics btv401.

Edlund, A., Hrdeman, F., Jansson, J.K., and Sjling, S. (2008) Active bacterial community structure along vertical redox gradients in Baltic Sea sediment. Environ Microbiol 10: 2051-2063.

Edwards, K.J., Rogers, D.R., Wirsen, C.O., and McCollom, T.M. (2003) Isolation and characterization of novel psychrophilic, neutrophilic, Fe-oxidizing, chemolithoautotrophic $\alpha$ and $\gamma$-Proteobacteria from the deep sea. Appl Environ Microb 69: 2906-2913.

Edwards, K.J., Wheat, C.G., and Sylvan, J.B. (2011) Under the sea: microbial life in volcanic oceanic crust. Nat Rev Microbiol 9: 703-712.

Ehrenreich, A., and Widdel, F. (1994) Anaerobic oxidation of ferrous iron by purple bacteria, a new type of phototrophic metabolism. Appl Environ Microb 60: 4517-4526.

Ehrlich, H.L., Newman, D.K., and Kappler, A. (2015) Ehrlich's Geomicrobiology: CRC press.

Emerson, D., and Moyer, C. (1997) Isolation and characterization of novel iron-oxidizing bacteria that grow at circumneutral pH. Appl Environ Microb 63: 4784-4792.

Emerson, D., and Moyer, C.L. (2010) Microbiology of Seamounts Common Patterns Observed in Community Structure. Oceanography 23: 148.

Emerson, D., Rentz, J.A., Lilburn, T.G., Davis, R.E., Aldrich, H., Chan, C., and Moyer, C.L. (2007) A novel lineage of proteobacteria involved in formation of marine Fe-oxidizing microbial mat communities. PloS One 2: e667.

Emerson, D., Fleming, E.J., and McBeth, J.M. (2010) Iron-oxidizing bacteria: an environmental and genomic perspective. Annu Rev Microbiol 64: 561-583.
Emerson, D., Scott, J.J., Benes, J., and Bowden, W.B. (2015) Microbial iron oxidation in the arctic tundra and its implications for biogeochemical cycling. Appl Environ Microb 81: 8066-8075.

Emmerich, M., Bhansali, A., Lösekann-Behrens, T., Schröder, C., Kappler, A., and Behrens, S. (2012) Abundance, distribution, and activity of Fe (II)-oxidizing and Fe (III)-reducing microorganisms in hypersaline sediments of Lake Kasin, southern Russia. Appl Environ Microb 78: 4386-4399.

Finneran, K.T., Housewright, M.E., and Lovley, D.R. (2002) Multiple influences of nitrate on uranium solubility during bioremediation of uranium-contaminated subsurface sediments. Environ Microbiol 4: 510-516.

Fitzsimmons, J.N., Boyle, E.A., and Jenkins, W.J. (2014) Distal transport of dissolved hydrothermal iron in the deep South Pacific Ocean. Proc Natl Acad Sci 111: 1665416661.

Fleming, E.J., Langdon, A.E., Martinez-Garcia, M., Stepanauskas, R., Poulton, N.J., Masland, E.D.P., and Emerson, D. (2011) What's new is old: resolving the identity of Leptothrix ochracea using single cell genomics, pyrosequencing and FISH. PloS One 6: e17769.

Froelich, P.N., Klinkhammer, G.P., Bender, M.L., Luedtke, N.A., Heath, G.R., Cullen, D., et al. (1979) Early oxidation of organic matter in pelagic sediments of the eastern equatorial Atlantic: suboxic diagenesis. Geochim Cosmochim Ac 43: 1075-1090.

Giling, D.P., Staehr, P.A., Grossart, H.P., Andersen, M.R., Boehrer, B., Escot, C., et al. (2017) Delving deeper: Metabolic processes in the metalimnion of stratified lakes. Limnol Oceanogr 62: 1288-1306.

Haines, M.G. (1959) The inverse skin effect. Proc Phys Soc 74: 576 .

Hallbeck, L., and Pedersen, K. (1991) Autotrophic and mixotrophic growth of Gallionella ferruginea. Microbiology 137: 2657-2661.

Heaviside, O. (1885) XLV. On the electromagnetic wave-surface. Lond Edinb Dubl Phil Mag 19: 397-419.

Hegler, F., Lösekann-Behrens, T., Hanselmann, K., Behrens, S., and Kappler, A. (2012) Influence of seasonal and geochemical changes on the geomicrobiology of an iron carbonate mineral water spring. Appl Environ Microb 78: 7185-7196.

Heising, S., Richter, L., Ludwig, W., and Schink, B. (1999) Chlorobium ferrooxidans sp. nov., a phototrophic green sulfur bacterium that oxidizes ferrous iron in coculture with a "Geospirillum" sp. strain. Arch Microbiol 172: 116-124.

Jiao, Y., Kappler, A., Croal, L.R., and Newman, D.K. (2005) Isolation and characterization of a genetically tractable photoautotrophic Fe (II)-oxidizing bacterium, Rhodopseudomonas palustris strain TIE-1. Appl Environ Microb 71: 44874496.

Jørgensen, B.B. (1977) The sulfur cycle of a coastal marine sediment (Limfjorden, Denmark). Limnol Oceanogr 22: 814-832.

Kappler, A., and Bryce, C. (2017) Cryptic biogeochemical cycles: unravelling hidden redox reactions. Environ Microbiol 19: 842-846.

Kappler, A., and Straub, K.L. (2005) Geomicrobiological cycling of iron. Rev Mineral Geochem 59: 85-108. 
Kasama, T., and Murakami, T. (2001) The effect of microorganisms on Fe precipitation rates at neutral pH. Chem Geol 180: 117-128.

Kato, S., Ohkuma, M., Powell, D.H., Krepski, S.T., Oshima, K., Hattori, M., et al. (2015) Comparative genomic insights into ecophysiology of neutrophilic, microaerophilic iron oxidizing bacteria. Front Microbio/ 6: 1265.

Kim, J.S., Im, S.H., and Park, G.S. (2017) A study on the skin effect and eddy current distributions in conductive media. In Electrical Machines and Systems (ICEMS), 201720 th International Conference on: IEEE, pp. 1-4.

Klueglein, N., Zeitvogel, F., Stierhof, Y.D., Floetenmeyer, M., Konhauser, K.O., Kappler, A., and Obst, M. (2014) Potential role of nitrite for abiotic $\mathrm{Fe}$ (II) oxidation and cell encrustation during nitrate reduction by denitrifying bacteria. Appl Environ Microbiol 80: 1051-1061.

Kozich, J.J., Westcott, S.L., Baxter, N.T., Highlander, S.K., and Schloss, P.D. (2013) Development of a dual-index sequencing strategy and curation pipeline for analyzing amplicon sequence data on the MiSeq Illumina sequencing platform. Appl Environ Microb 79: 5112-5120.

Krepski, S.T., Hanson, T.E., and Chan, C.S. (2012) Isolation and characterization of a novel biomineral stalk-forming iron-oxidizing bacterium from a circumneutral groundwater seep. Environ Microbiol 14: 1671-1680.

Kucera, S., and Wolfe, R. (1957) A selective enrichment method for Gallionella ferruginea. J Bacteriol 74: 344.

Lamb, H. (1883) On electrical motions in a spherical conductor. Proc R Soc London 35: 130-132.

Laufer, K. (2016) Abundance, distribution, and activity of anaerobic and microaerophilic $\mathrm{Fe}(\mathrm{II})$-oxidizing and anaerobic Fe(III)-reducing microorganisms in coastal marine sediments. Dissertation of University of Tuebingen.

Laufer, K., Nordhoff, M., Røy, H., Schmidt, C., Behrens, S., Jørgensen, B.B., and Kappler, A. (2016) Coexistence of microaerophilic, nitrate-reducing, and phototrophic Fe (II) oxidizers and Fe (III) reducers in coastal marine sediment. Appl Environ Microb 82: 1433-1447.

Laufer, K., Nordhoff, M., Halama, M., Martinez, R., Obst, M., Nowak, M., et al. (2017) Microaerophilic Fe (II)-oxidizing Zetaproteobacteria isolated from low-Fe marine coastal sediments: physiology and composition of their twisted stalks. Appl Environ Microb 83: e03118-16-e03116.

Lehto, N., Glud, R.N., Á Norði, G., Zhang, H., and Davison, W. (2014) Anoxic microniches in marine sediments induced by aggregate settlement: Biogeochemical dynamics and implications. Biogeochemistry 119: 307-327.

Li, X., Zhang, W., Liu, T., Chen, L., Chen, P., and Li, F. (2016) Changes in the composition and diversity of microbial communities during anaerobic nitrate reduction and Fe (II) oxidation at circumneutral $\mathrm{pH}$ in paddy soil. Soil Biol Biochem 94: 70-79.

Li, Y., Yu, S., Strong, J., and Wang, H. (2012) Are the biogeochemical cycles of carbon, nitrogen, sulfur, and phosphorus driven by the "Felll-Fell redox wheel" in dynamic redox environments?. J Soils and Sediments 12: 683-693.

Lovley, D. (2006) Dissimilatory Fe (III)-and Mn(IV)-reducing prokaryotes. In The Prokaryotes: Springer, pp. 635-658.

Lovley, D. (2013) Dissimilatory Fe (III)-and Mn(IV)-reducing prokaryotes. In The Prokaryotes: Springer, pp. 287-308.
Lovley, D.R. (2017) Happy together: microbial communities that hook up to swap electrons. Isme J 11: 327.

Loy, A., Lehner, A., Lee, N., Adamczyk, J., Meier, H., Ernst, J., et al. (2002) Oligonucleotide microarray for 16S rRNA gene-based detection of all recognized lineages of sulfatereducing prokaryotes in the environment. Appl Environ Microb 68: 5064-5081.

Lücker, S., Steger, D., Kjeldsen, K.U., MacGregor, B.J., Wagner, M., and Loy, A. (2007) Improved 16S rRNAtargeted probe set for analysis of sulfate-reducing bacteria by fluorescence in situ hybridization. $J$ Microbiol Methods 69: 523-528.

Ludwig, W., Strunk, O., Westram, R., Richter, L., Meier, H., Yadhukumar., et al. (2004) ARB: a software environment for sequence data. Nucleic Acids Res 32: 1363-1371.

Malkin, S., and Meysman, F. (2015) Rapid redox signal transmission by "cable bacteria" beneath a photosynthetic biofilm. Appl Environ Microb 81: 948-956.

Martin, M. (2011) Cutadapt removes adapter sequences from high-throughput sequencing reads. EMBnetjournal, North America 17: 10-12.

Marzocchi, U., Trojan, D., Larsen, S., Meyer, R.L., Revsbech, N.P., Schramm, A., et al. (2014) Electric coupling between distant nitrate reduction and sulfide oxidation in marine sediment. Isme J 8: 1682-1690.

Melton, E.D., Schmidt, C., and Kappler, A. (2012) Microbial iron (II) oxidation in littoral freshwater lake sediment: the potential for competition between phototrophic vs. nitratereducing iron (II)-oxidizers. Front Microbio/ 3: 197.

Melton, E.D., Schmidt, C., Behrens, S., Schink, B., and Kappler, A. (2014a) Metabolic flexibility and substrate preference by the Fe (II)-oxidizing purple non-sulphur bacterium Rhodopseudomonas palustris strain TIE-1. Geomicrobiol $J$ 31: 835-843.

Melton, E.D., Swanner, E.D., Behrens, S., Schmidt, C., and Kappler, A. (2014b) The interplay of microbially mediated and abiotic reactions in the biogeochemical Fe cycle. Nat Rev Microbiol 12: 797-808.

Mori, J.F., Scott, J.J., Hager, K.W., Moyer, C.L., Küsel, K., and Emerson, D. (2017) Physiological and ecological implications of an iron-or hydrogen-oxidizing member of the Zetaproteobacteria, Ghiorsea bivora, gen. nov., sp. nov. Isme $J$ 11: 2624.

Nielsen, L.P., and Risgaard-Petersen, N. (2015) Rethinking sediment biogeochemistry after the discovery of electric currents. Annu Rev Mar Sci 7: 425-442.

Nielsen, L.P., Risgaard-Petersen, N., Fossing, H., Christensen, P.B., and Sayama, M. (2010) Electric currents couple spatially separated biogeochemical processes in marine sediment. Nature 463: 1071-1074.

Orcutt, B.N., Sylvan, J.B., Knab, N.J., and Edwards, K.J. (2011) Microbial ecology of the dark ocean above, at, and below the seafloor. Microbiol Mol Biol R 75: 361-422.

Oswald, K., Graf, J.S., Littmann, S., Tienken, D., Brand, A., Wehrli, B., et al. (2017) Crenothrix are major methane consumers in stratified lakes. Isme J 11: 2124.

Parks, D.H., Tyson, G.W., Hugenholtz, P., and Beiko, R.G. (2014) STAMP: statistical analysis of taxonomic and functional profiles. Bioinformatics 30: 3123-3124.

Peng, Q-A., Shaaban, M., Wu, Y., Hu, R., Wang, B., and Wang, J. (2016) The diversity of iron reducing bacteria 
communities in subtropical paddy soils of China. App/ Soil Ecol 101: 20-27.

Pfeffer, C., Larsen, S., Song, J., Dong, M., Besenbacher, F., Meyer, R.L., et al. (2012) Filamentous bacteria transport electrons over centimetre distances. Nature 491: 218-221.

Picardal, F. (2012) Abiotic and Microbial Interactions during Anaerobic Transformations of Fe(II). Front Microbio/ 3: 112.

Pruesse, E., Quast, C., Knittel, K., Fuchs, B.M., Ludwig, W., Peplies, J., and Glöckner, F.O. (2007) SILVA: a comprehensive online resource for quality checked and aligned ribosomal RNA sequence data compatible with ARB. Nucleic Acids Res 35: 7188-7196.

Pruesse, E., Peplies, J., and Glöckner, F.O. (2012) SINA: accurate high-throughput multiple sequence alignment of ribosomal RNA genes. Bioinformatics 28: 1823-1829.

Rao, A.M., Malkin, S.Y., Hidalgo-Martinez, S., and Meysman, F.J. (2016) The impact of electrogenic sulfide oxidation on elemental cycling and solute fluxes in coastal sediment. Geochim Cosmochim Ac 172: 265-286.

Rao, T., Sairam, T., Viswanathan, B., and Nair, K. (2000) Carbon steel corrosion by iron oxidising and sulphate reducing bacteria in a freshwater cooling system. Corrosion Science 42: 1417-1431.

Revil, A., Mendonça, C., Atekwana, E., Kulessa, B., Hubbard, S., and Bohlen, K. (2010) Understanding biogeobatteries: Where geophysics meets microbiology. J Geophys Res Biogeosci 115: 1.

Reyes, C., Dellwig, O., Dähnke, K., Gehre, M., NoriegaOrtega, B.E., Böttcher, M.E., et al. (2016) Bacterial communities potentially involved in iron-cycling in Baltic Sea and North Sea sediments revealed by pyrosequencing. FEMS Microbiol Ecol 92: fiw054.

Richards, F.A. (1965) Anoxic basins and fjords. Chemical Oceanography 1: 611-643.

Risgaard-Petersen, N., Revil, A., Meister, P., and Nielsen, L.P. (2012) Sulfur, iron-, and calcium cycling associated with natural electric currents running through marine sediment. Geochim Cosmochim Ac 92: 1-13.

Risgaard-Petersen, N., Kristiansen, M., Frederiksen, R.B., Dittmer, A.L., Bjerg, J.T., Trojan, D., et al. (2015) Cable bacteria in freshwater sediments. Appl Environ Microb 81: 6003-6011.

Roden, E.E. (2004) Analysis of long-term bacterial vs. chemical Fe (III) oxide reduction kinetics. Geochim Cosmochim Ac 68: 3205-3216.

Rotaru, A.-E., Shrestha, P.M., Liu, F., Markovaite, B., Chen, S., Nevin, K.P., and Lovley, D.R. (2014) Direct interspecies electron transfer between Geobacter metallireducens and Methanosarcina barkeri. Appl Environ Microb 80: 45994605.

Schloss, P.D., Westcott, S.L., Ryabin, T., Hall, J.R., Hartmann, M., Hollister, E.B., et al. (2009) Introducing mothur: opensource, platform-independent, community-supported software for describing and comparing microbial communities. Appl Environ Microb 75: 7537-7541.

Schloss, P.D., Gevers, D., and Westcott, S.L. (2011) Reducing the effects of PCR amplification and sequencing artifacts on 16S rRNA-based studies. PloS One 6: e27310.

Schmidt, C., Behrens, S., and Kappler, A. (2010) Ecosystem functioning from a geomicrobiological perspective-a conceptual framework for biogeochemical iron cycling. Environ Chem 7: 399-405.

Seitaj, D., Schauer, R., Sulu-Gambari, F., Hidalgo-Martinez, S., Malkin, S.Y., Burdorf, L.D., et al. (2015) Cable bacteria generate a firewall against euxinia in seasonally hypoxic basins. Proc Natl Acad Sci 112: 13278-13283.

Shi, L., Dong, H., Reguera, G., Beyenal, H., Lu, A., Liu, J., et al. (2016) Extracellular electron transfer mechanisms between microorganisms and minerals. Nat Rev Microbiol 14: 651-662.

Sinkko, H., Lukkari, K., Jama, A.S., Sihvonen, L.M., Sivonen, K., Leivuori, M., et al. (2011) Phosphorus chemistry and bacterial community composition interact in brackish sediments receiving agricultural discharges. PloS One 6: e21555.

Straub, K.L., Benz, M., Schink, B., and Widdel, F. (1996) Anaerobic, nitrate-dependent microbial oxidation of ferrous iron. Appl Environ Microb 62: 1458-1460.

Straub, K.L., Rainey, F.A., and Widdel, F. (1999) Rhodovulum iodosum sp. nov. and Rhodovulum robiginosum sp. nov., two new marine phototrophic ferrous-iron-oxidizing purple bacteria. Int J Syst Evol Microbiol 49: 729-735.

Sulu-Gambari, F., Seitaj, D., Meysman, F.J., Schauer, R., Polerecky, L., and Slomp, C.P. (2016) Cable bacteria control iron-phosphorus dynamics in sediments of a coastal hypoxic basin. Environ Sci Technol 50: 1227-1233.

Thamdrup, B., Fossing, H., and Jørgensen, B.B. (1994) Manganese, iron and sulfur cycling in a coastal marine sediment, Aarhus Bay, Denmark. Geochim Cosmochim Ac 58: 5115-5129.

Thar, R., and Fenchel, T. (2005) Survey of motile microaerophilic bacterial morphotypes in the oxygen gradient above a marine sulfidic sediment. Appl Environ Microb 71: 36823691.

Thompson, K.J., Simister, R.L., Hahn, A.S., Hallam, S.J., and Crowe, S.A. (2017) Nutrient acquisition and the metabolic potential of photoferrotrophic Chlorobi. Frontiers in Microbiology 8: 1212.

Vasquez-Cardenas, D., Van De Vossenberg, J., Polerecky, L., Malkin, S.Y., Schauer, R., Hidalgo-Martinez, S., et al. (2015) Microbial carbon metabolism associated with electrogenic sulphur oxidation in coastal sediments. Isme $J$ 9: 1966-1978.

Wang, Q., Garrity, G.M., Tiedje, J.M., and Cole, J.R. (2007) Naive Bayesian classifier for rapid assignment of rRNA sequences into the new bacterial taxonomy. Appl Environ Microb 73: 5261-5267.

Weber, K.A., Urrutia, M.M., Churchill, P.F., Kukkadapu, R.K., and Roden, E.E. (2006a) Anaerobic redox cycling of iron by freshwater sediment microorganisms. Environ Microbiol 8: 100-113.

Weber, K.A., Pollock, J., Cole, K.A., O'Connor, S.M., Achenbach, L.A., and Coates, J.D. (2006b) Anaerobic nitrate-dependent iron(II) bio-oxidation by a novel lithoautotrophic betaproteobacterium, strain 2002. Appl Environ Microb 72: 686-694.

Weiss, J.V., Rentz, J.A., Plaia, T., Neubauer, S.C., MerrillFloyd, M., Lilburn, T., et al. (2007) Characterization of neutrophilic Fe (II)-oxidizing bacteria isolated from the rhizosphere of wetland plants and description of Ferritrophicum 
radicicola gen. nov. sp. nov., and Sideroxydans paludicola sp. nov. Geomicrobiol J 24: 559-570.

Wheeler, H.A. (1942) Formulas for the skin effect. Proc IRE 30: 412-424.

Widdel, F., Schnell, S., Heising, S., Ehrenreich, A., Assmus, B., and Schink, B. (1993) Ferrous iron oxidation by anoxygenic phototrophic bacteria. Nature 362: 834-836.

Winogradsky, S. (1888) Beitrage zur Morphologie und Physiologie der Bakterien. I. Zur Morphologie and Physiologie der Schwefelbakterien. A. Felix, Leipzig. 1949 Revision. Republished as Contribution a la morphologie et physiologie des sulfobacteries: Microbiologie du sol. Massonet Cie, Paris.

Wu, L., Wang, J., Tang, P., Chen, H., and Gao, H. (2011) Genetic and molecular characterization of flagellar assembly in Shewanella oneidensis. PloS One 6: e21479.

Wu, W., Swanner, E.D., Hao, L., Zeitvogel, F., Obst, M., Pan, Y., and Kappler, A. (2014) Characterization of the physiology and cell-mineral interactions of the marine anoxygenic phototrophic Fe (II) oxidizer Rhodovulum iodosum-implications for Precambrian Fe (II) oxidation. FEMS Microbiol Ecol 88: 503-515.

\section{Supporting information}

Additional supporting information may be found in the online version of this article at the publisher's website:

Fig. S1. Absolute abundance of bacteria and archaea based on qPCR analysis specific for 16S rRNA genes (based on DNA).

Fig. S2. Absolute abundance of bacteria based on qPCR analysis specific for 16S rRNA (based on RNA).

Fig. S3. PCoA-Plots for the $(A)$ marine and $(B)$ freshwater sediment community showing clear differences of RNA and
DNA sequence analyses and differences of the two marine sampling sites (Norsminde Fjord and Kalø Vig).

Fig. S4. Taxonomic identification of the microbial communities in Kalø Vig, Norsminde Fjord and Lake Constance sediments based on 16S rRNA (gene) amplicon analysis comparing DNA- and RNA-based findings. Data were averaged among sediment depth layers and replicate cores.

Fig. S5. Microscopic images of cable bacteria from Aarhus sediment provided by Jesper T. Bjerg (Aarhus University).

Fig. S6. Comparison of Spearman's rank correlation values of Fe-cycling bacteria and cable bacteria from Kalø Vig and Norsminde Fjord.

Fig. S7. Sediment cores from Norsminde Fjord, Kalø Vig and Lake Constance.

Table S1. Microbial diversity indices for all sampling sites (Chao index, Shannon index, Simpson index).

Table S2. Most abundant genera of Norsminde Fjord, Kalø Vig and Lake Constance as well as implications for metabolic processes.

Table S3. Abundant present (DNA based) and active (RNA based) genera of Norsminde Fjord, Kalø Vig and Lake Constance sediment.

Table S4. Overview of iron-metabolizing microorganisms that were analysed in this study.

Table S5. Overview of iron-metabolizing isolates from (A) Kalø Vig and Norsminde Fjord from Laufer et al., 2016, as well as from (B) Lake Constance sediment (personal communication with Franziska Schädler, University of Tübingen).

Table S6. Spearman correlation test with Fe(II)-oxidizers and Fe(III)-reducers from (A) Kalø Vig, (B) Norsminde Fjord and (C) Lake Constance sediment. 